\title{
UN Representation Disputes: A Case Study of Cambodia and a New Accreditation Proposal for the Twenty-First Century
}

\author{
Suellen Ratliff $\dagger$
}

The United Nations approves and accepts the representatives of its member states through a procedural accreditation process involving its Credentials Committee and the General Assembly. In'most cases, the Credentials Committee verifies that the representative's credentials are in order and the General Assembly approves the representative as a matter of course. Complications arise, however, when a member state experiences an internal dispute resulting in rival governments that each indicate their intent to represent the member state in the UN. Faced with multiple sets of credentials for a single member state, the Credentials Committee and the General Assembly must choose which government will represent the member state. Though the General Assembly addressed the resolution of representation disputes almost fifty years ago, it failed to adopt sufficiently structured guidelines to achieve a consistent process for resolving these disputes. As a result, member states within the Credentials Committee and the General Assembly may manipulate the process by applying completely different guidelines to each representation dispute. Such manipulations may further the political interests of individual member states, but they also may harm the UN's integrity by seating representatives who do not truly represent the interests of the member state's population.

This Comment highlights the inadequacies of the existing UN process used to resolve representation disputes by analyzing the evolution of the current guidelines and their application to three representation disputes in

Copyright $\odot 1999$ California Law Review, Inc.

$\dagger \quad$ Law clerk to the Honorable John Hannah, Jr., U.S. District Court for the Eastern District of Texas; J.D., School of Law, University of California, Berkeley (Boalt Hall), 1999; B.A., University of Oregon, 1993. I wish to thank Professor Patti Blum for her insightful feedback throughout the writing process; the University of San Francisco School of Law for allowing me to participate in its Law and Democracy Program in Phnon Penh, Cambodia, in 1997, the experience which originally inspired this Comment; the editors and inembers of the California Law Review for their diligent work in improving this Comment; and all iny loved ones for their unflagging support and steadfast belief in me. 
Cambodia since 1970. Comparison of the different criteria applied in each dispute demonstrates how member states manipulate the accreditation process to achieve political ends, even when the chosen representative clearly does not represent the people of the member state. In addition to this historical analysis, the Comment examines the emergence and importance of human rights law in the international community, and the role human rights should play in the resolution of UN representation disputes. Ultimately, this Comment offers a new Accreditation Proposal for resolving UN representation disputes. The Proposal requires both the Credentials Committee and the General Assembly to apply a four-factor balancing test in every future representation dispute, and includes, as one of these factors, an explicit consideration of human rights. Application of this balancing test to the three Cambodian representation disputes shows the effectiveness of a consistent and structured process for determining UN representation.

\section{INTRODUCTION}

The government of the Khmer Rouge, under the leadership of Pol Pot, committed auto-genocide ${ }^{1}$ against approximately two million Cambodians between 1975 and $1979 .{ }^{2}$ Yet the Khmer Rouge government officially represented Cambodia in the United Nations ("UN") General Assembly until 1990. The UN Senior Advisor to Cambodia likened the Khmer Rouge to Hitler's Germany, observing that "[s]ome of the methods of torture and execution were, if anything, more obscene than those practised by the Nazis and degraded the human mind and body in ways never before known." ${ }^{3}$ Despite the atrocities committed against its own people, and despite its lack of control over the majority of Cambodia's population and territory, the Khmer Rouge government occupied Cambodia's General Assembly seat for eleven years after the end of the "killing fields."

1. Auto-geuocide is a term of art coined in reference to the mass killings of Cambodians at the hands of their own government. It should be noted that a majority of the killings would not technically qualify as genocide under existing internatioual law, however, because a large number of the executions were based on political or educational affiliation-categories not included in the widely accepted definition of genocide under Article $I I$ of the Convention on the Prevention and Punishment of the Crime of Genocide. See Convention on the Prevention and Punishment of the Crime of Genocide, adopted by the UN General Assembly Dec. 8, 1948, 78 U.N.T.S. 277 (entered into force Jan. 12, 1951).

2. See Lawyers Commitee for Human Rights, Cambodia: The Justice System and Violations of Human Rights 14 (1992); Donald M. Seekins, Historical Setting, in Cambodia: A COUNTRY Study 75 (Russell R. Ross ed., 3d ed. 1990).

3. GaRy KuINTworth, Vietnam's Intervention In Cambodia In INTERnational Law 6-7 (1989) (quoting Sir Robert Jackson, Under-Secretary-General and Senior Advisor to the UN).

4. The factors that played into the international reaction, or lack of reaction, to the seating of the Khmer Rouge government in the UN are complex and involve geo-political decisions that cannot be adequately dealt with here. The complexity of the situation in South East Asia during the Vietnam War era and the U.S. role in the region, should uot be glossed over. Wheu Vietnam intervened in Cambodia 
This outcome resulted from the UN's procedure for determining which government of a particular UN member state will represent that state in the UN when more than one government claims authority over the state. ${ }^{5}$ Disputes over UN representation have arisen since the UN's inception in states experiencing civil unrest, where the rulimg government has been overthrown or challenged. Major disputes over UN representation have involved China, Hungary, the Congo, Yemen, Israel, South Africa, Cambodia, and Afghamistan. ${ }^{6}$ As long as member states continue to suffer from civil strife imvolving power struggles between various régimes, the resolution of UN representation disputes will remam important. However, the UN procedures which allowed the Khmer Rouge to represent Cambodia remain unchanged to date. No safeguards exist to prevent such a result from occurring im the future.

Under present UN procedure, when rival governments concurrently claim to represent a UN member state, the decision of which government to accredit is not guided by consideration of any specific criteria. As a result, other member states maintain the ability to manipulate decisions on representation to further their states' individual political goals, and they do so with impunity. In addition, the existing accreditation procedures for determining representation lack the substantive foundation necessary to derive consistent outcomes on this issue. ${ }^{7}$ The problem is not that the decisions reached in representation disputes are different; it is natural that the circunistances unique to each representation dispute might lead to varied results. The problem lies in the inconsistent processes by which the UN reaches those decisions. The lack of a consistent decision-making process allows politically motivated member states to achieve their desired results without accountability and without consideration of the legal norms of the modern international community. Discrepancies in the resolutions of representation disputes within member states should be the result of the disputes' differmg circumstances, not the result of different political interests of the member states making the decision.

and replaced the Khmer Rouge with a Vietnamese-backed government, the international reaction was swift and extremely negative. My analysis of the UN decision to seat the Khmer Rouge government, rather than the Vietnamese-backed government, necessarily contains some discussion of the political justifications for the outcome, but does not delve deeply into the political tensions. For additional discussion of this issue, sec generally KLINTWORTH, supra note 3.

5. Countries are referred to as states in imternational law. At present, 185 states are members of the UN. See UNITED Nations HaNdBooK 1997, at 11 (35th ed. 1997).

6. See Yehuda Z. Blum, ERoding the United Nations Charter 33-56 (1993); Brad R. Roth, Governmental Illegitimacy in International Law: An Emerging Norm im Theoretical Perspective 411-57 (1996) (Ph.D. dissertation, Univ. of Cal. (Berkeley)), microformed on UMI 9723163 (Univ. Microforms Int'l).

7. For example, the UN resolved the two most recent representation disputes, occurring in Cambodia and Afghamistan in 1997, differently. See Report of the Credentials Comm., U.N. GAOR, 52d Sess., Agenda Item 3, I 4, at 1, II 9, at 3, U.N. Doc. A/52/719 (1997). 
Achieving consistent outcomes within a UN decision-making process requires clear and definite guidelines for nember states to follow. Such guidelines should consider a variety of factors, including the human rights record of each government claiming the right of representation. International hunian rights law is a normative facet of the international legal régime. The question of what weight, if any, human rights law should be given in international decisions remains highly debated. Part I of this Comment joins this debate on a limited scale by discussing the rapid ascent and continued growth of human rights law over the past fifty years, especially within the $\mathrm{UN}$, and asserting that the $\mathrm{UN}$ is in a unique position to protect the human rights of individuals through its internal mechanisms, including the accreditation process. ${ }^{8}$

With this context in mind, Part II addresses the logistics of the representation issue within the UN. Section A describes the fora available to decide matters of representation, focusing on the UN Credentials Committee as the principle forum for determining which group the UN will accept as a member state's representative. In addition, Section A discusses how the UN General Assembly often must undertake further deliberations when rival governments concurrently claim the right to represent a niember state. Section B then analyzes the evolution of the current accreditation process and the various criteria proposed over time for dealing with issues of representation. This examination sets forth the spectruin of potential factors the UN should consider in determining representation, and highlights the inadequacies of the current accreditation guidelines.

In Part III, I present my Accreditation Proposal for the United Nations to consider. Responding to the shortcomings of the current accreditation guidelines, this Accreditation Proposal contains a clear set of criteria in the form of a balancing test to guide the UN's substantive evaluation of governments claiming to represent a member state. My Accreditation Proposal focuses on factors that tend to indicate the representative nature of a particular governinent, including mandatory consideration of human rights law. Ensuring that the sanie criteria will be evaluated, weighed, and balanced in every representation dispute will increase the consistency of outcomes in similar circuinstances and decrease the ability of member

8. Although "representation" and "accreditation" share a close relationship in practice because the accreditation of a delegation's credentials is premised on the concept of representation, it is important to separate them as legal concepts. See Farrokh Jhabvala, The Credentials Approach to Representation Questions in the United Nations General Assembly, 7 CAL. W. INT'L L.J. 615, 636 (1977). As early as 1950, UN representatives recognized this distinction: "Credentials merely accredit the powers conferred by a government ou its representatives; representation, on the other hand, is the right of a government to act on behalf of the State." U.N. GAOR, 5th Sess., Annexes, Agenda Item 61, at 3, U.N. Doc. A/1308 (1950). By its very nature, the credentials process is procedural-it merely verifies the authenticity of the credentials document that a delegation presents to the UN. The inquiry into representation, however, is substantive because it questions whether a government legitimately represents the state. 
states to manipulate the accreditation process for their own ends. To further advance these goals, my Accreditation Proposal requires that both the Credentials Committee and the General Assembly separately consider these criteria.

Part IV presents a case study of three representation disputes within Cambodia since 1970, and analyzes the ultimate resolution of each dispute. This analysis reveals significant differences in the evaluation and resolution of accreditation disputes within a single member state on three separate occasions: in 1973, in 1979, and in 1997. These inconsistent practices demonstrate the need for a clear set of criteria to guide resolution of representation disputes between rival governments in the future. Following the historical analysis of each dispute is a discussion of how application of the balancing test in my Accreditation Proposal might have affected the outcome of that particular dispute. Certainly, the Accreditation Proposal's balancing test would have prevented the Khmer Rouge government from officially representing Cambodia in the Umited Nations, and, if applied to future representation disputes, will prevent such a perversity from ever occurring agam.

\section{Human Rights IN THE INTERNATIONAL LEGAL RÉGIME}

International human rights law has been the focus of increasmg attention, both positive and negative, over the past fifty years. With assertions of the need for umiversal enforcement of human rights come questions regarding the right of the international community to pass judgment on the human rights records of other sovereign states. What right do states-most likely guilty of human rights violations in their own past-have to stand in judgment over other, less developed states? Why should the UN, a political imstitution, ${ }^{9}$ even consider human rights in deciding which of two rival governments will represent a nember state? In addressing these concerns, the status of human rights in the international legal régime becomes clear. Not only does human rights law occupy a inore important role within the international commumity now than it did fifty years ago; that role continues to expand in breadth and status. Further, the UN's historic role in advancing human rights law ${ }^{10}$ supports the appropriate inclusion of hunian rights considerations im my Accreditation Proposal.

9. The UN is clearly a political institution in the sense that it is an intergovernmental organization. Its members are political states, and its decisions involve the political relationships between those states. Despite its political nature, the UN accepts responsibility through its Charter for upholding and furthering international law, mcluding human rights. See U.N. CharTer preamble, art. 1.

10. See discussion infra Part I.B. 


\section{A. The Growth of Human Rights Law in the International Community}

The international community has undergone significant change, both political and social, since the end of World War II. Increased focus on normative issues such as human rights constitutes one of the nuore significant changes. ${ }^{11}$ Nunierous inultilateral treaties and conventions beginning in the late 1940s aimed to protect affirmatively "human rights"12 and to eliminate scourges such as genocide, ${ }^{13}$ racial discrimination, ${ }^{14}$ gender discrimination, ${ }^{15}$ and torture. ${ }^{16}$ Over time, nost UN meinber states have come to agree, in primciple, that human rights violations such as genocide, slavery, and torture should be universally condemned; thus, these violations have become part of international customary law that is binding on all states. ${ }^{17}$

11. See Phillip R. Trimble, Globalization, International Institutions, and the Erosion of National Sovereignty and Democracy, 95 Mich. L. REv. 1944, 1949 (1997) (book review) (reviewing ThomAS M. FRANCK, FaIRNESS IN INTERNATIONAL LAW AND INSTITUTIONS (1995)). Other indications of the increased focus on human rights include the 1970 International Court of Justice opinion in Barcelona Traction, Light and Power Co. Ltd., 1970 I.C.J. 3 (February 5), where the court held that states may have obligations erga omnes (meaning toward the international community of states as a whole, as opposed to obligations that extend only to one state) on which a suit might be based. This decision indicates a change from the traditional state-centered view where each state only meurred duties against other individual states as a result of one-to-oue state relations. See DAvid H. OTT, PUblic INTERNATIONAL LAW IN THE MODERN WORLD 245 (1987).

12. See generally Convention on the Rights of the Child, G.A. Res. 44/25, U.N. GAOR, 44th Sess., Supp. No. 49, at 166, U.N. Doc. A/44/49 (1989) (entered into force Sept. 2, 1990); African [Banjul] Charter on Human and Peoples' Rights, adopted June 27, 1981, Organization of African Unity Doc. CAB/LEG/67/3/Rev.5, 21 I.L.M. 58 (entered into force Oct. 21, 1986); American Convention on Human Rights, Nov. 22, 1969, Organization of American States, Treaty Series No. 36, at 1, OEA/Ser.A./16 (entered into force July 18, 1978); International Covenant on Civil and Political Rights, adopted by UN General Assembly Dec. 19, 1966, 999 U.N.T.S. 171 (entered into force Mar. 23, 1976); International Covenant on Economic, Social and Cultural Rights, adopted by UN General Assembly Dec. 16, 1966, 993 U.N.T.S. 3 (entered into force Jan. 3, 1976); Convention Relating to the Status of Refugees, July 28, 1951, 189 U.N.T.S. 150 (entered into force Apr. 22, 1954); [Buropean] Convention for the Protection of Human Rights and Fundamental Freedoms, Nov. 4, 1950, 213 U.N.T.S. 222 (entered into force Sept. 3, 1953).

13. See Convention on the Prevention and Punishment of the Crime of Genocide, adopted by the UN General Assembly Dec. 9, 1948, 78 U.N.T.S. 277 (entered into force Jan. 12, 1951).

14. See International Convention on the Elimination of All Forms of Racial Discrimination, opened for signature Mar. 7, 1966, 660 U.N.T.S. 195 (entered into force Jan. 4, 1969).

15. See Convention on the Elimination of All Forms of Discrimination Against Women, G.A. Res. 34/180, U.N. GAOR, 34th Sess., Supp. No. 46, at 193, U.N. Doc. A/34/180 (entered into force Sept. 3, 1981).

16. See Convention Against Torture and Other Crnel, Inhuman or Degrading Treatment or Punishment, G.A. Res. 39/46, U.N. GAOR, 39th Sess., Supp. No. 51, at 197, U.N. Doc. A/39/51 (1984) (entered into force June 26, 1987).

17. See antonio Cassese, Human Rights in a Changing World 167-68 (1990); Trimble, supra note 11, at 1955; see also Bruno Simma, Human Rights, in THE UNITED NATIONS AT AGE FIFTY 264 (Christian Tomuschat ed., 1995) ("[A] growing part of the international legal profession appears to accept that at least a core of hunan rights obligations can nowadays be considered as anehored in customary international law."). 
Some scholars explain this consensus among states through a framework of successive "generations" of human rights. ${ }^{18}$ This generational framework does not describe the progression of human rights in practice. Rather, it describes the conceptual progression of human rights within the international community. The first generation of imternational human rights focused on the civil and political rights of the individual against the state. This generation formed the backbone of important imternational law documents such as the Universal Declaration of Human Rights ${ }^{19}$ and the International Convention on Civil and Political Rights. ${ }^{20}$ The second generation extended human rights to mclude affirmative social and cultural rights, requirmg state intervention to achieve fair social circumstances and conditions for individuals. ${ }^{21}$ Thus, in the first and second generations, states were primarily concerned with the rights of individual citizens in relation to other citizens and to the state. In the current third generation, however, the focus of international human rights has shifted to "transcend national boundaries and may be thought of as rights against the international community of states as a whole."22 This third generation of human rights points out the need for an interdependent relationship between states and between the imdividuals within all states. ${ }^{23}$ This notion of interdependence carries beyond state-based relationships to the overarching connection between all human beings. Thus, the third generation supports the concept of umiversal human rights which are shared by all people, regardless of state boundaries.

Critics of this generational framework may charge that it describes only the western or industrialized concept of human rights, and that it does not reflect the human rights concepts of other political systems or less developed states. Thus, while western or industrialized states may be capable of and willing to respect so-called third generation human rights, other

18. See OTT, supra note 11 , at 238 . Ott notes that this analysis cannot be applied "too rigorously," but that it assists in understanding the formation of human rights law. Id.; see also Simma, supra note 17, at 276 (making a distinction between first generation, concerned with civil and pohtical rights, and second generation, concerned with social and cultural rights). For a discussion of the international community before the emergence of modern human rights, sce CASSESE, supra note 17, at 11-14.

19. G.A. Res. 217(W)(A), U.N. Doc. A/810, at 71 (1948) [herenafter Universal Declaration of Human Rights].

20. G.A. Res. 2200A (XXI), U.N. GAOR, Supp. No. 16, at 52, U.N. Doc. A/6316 (1966), reprinted in 999 U.N.T.S. 171 (entered into force March 23, 1976); see OTT, supra note 11, at 239; Sinma, supra note 17, at 276 (discussing the role of early human rights docunents in the first generation of international human rights law).

21. See OTr, supra note 11 , at 242 . Ott notes that the International Labour Organisation (ILO), formed in 1919, was the most effective promoter of second generation rights. Id. at 243; see also Simma, supra note 17 , at 276.

22. OTт, supra note 11, at 244; see also Thomas M. Franck, The Emerging Right to Democratic Governance, 86 AM. J. INT'L L. 46, 79 (1992).

23. See OTT, supra note 11 , at 244. 
states should not be forced to accept or adhere to those rights. This argument implies that human rights are only relevant to particular types of culture and government. ${ }^{24}$

Another argument against international human rights standard is that western and industrialized states should not pass judgment on other states when they have violated their own citizens' human rights at some point in their own development. Certainly, developed states are hypocritical if they assume an air of innocence in judging less developed states' human rights violations today; however, the basis of such an argument-that developed states' past violations of human rights somehow validate less developed states' current violations of human rights-cannot stand. One state's past violations do not make another state's present violations acceptable. Rather, where states at all levels of development have reached consensus on human rights norms, the states that are better able to achieve those norms have a responsibility to assist states that may lack the resources or capability to fully comply with the human rights standards they have set for themselves. Further, the international community as a whole should utilize international organizations in assisting states, either directly or indirectly, to achieve human rights standards. International organizations dealing with peace and security, finance, trade, and financial relief can help create international conditions facilitating the fulfillinent of human rights standards. ${ }^{25}$

The debate on these issues rages in continuous circles without reachmg a definitive answer. The fact remains that human rights law has become a reality within the international community and inust be dealt with as such. The argument of state sovereignty can no longer shut out consideration of human rights; though sovereignty still occupies an important place in international law, the concept is changing from protection of the sovereign's sovereignty to protection of the people's sovereignty. ${ }^{26}$ Judge

24. This argument is valid, but goes far beyond what can be dealt with adequately in the confines of this Comment. For a discussion of the approach of different cultures to human rights law, sce A.H. Robertson \& J.G. MERRILLS, Human Rights IN THE WORLD 2-15 (4th ed. 1996). Robertson and Merrills note that the notion of "individual rights" dates back thousands of years to Cyrus the Great, ancient Egyptian pharaohs, and Ancient Babylon; thus, they conclude that the "worth of the individual" cannot be categorized as belonging to western societies alone. Id. at 7-8.

25. The Vienna Declaration and Programme of Action adopted at the World Conference on Human Rights in 1993 recognized that "[d]emocracy, development and respect for human rights and fundamental freedoms are interdependent and mutually reinforcing. ... The international community should support the strengthening and promoting of democracy, development and respect for human rights and fundamental freedoms in the entire world." Report of the World Conference on Human Rights: Report of the Secretary-General, U.N. GAOR, I 8, at 23, U.N. Doc. A/CONF.157/24 (Part I) (1993).

26. See W. Michael Reisman, Sovereignty and Human Rights in Contemporary International Law, 84 AM. J. INT'i L. 866, 869 (1990), reprinted in HeNRY J. STEINER \& Philip Alston, INTERNATIONAL Human RIghtS in CONTEXT 157, 158 (1996); see also Trimblc, supra note 11, at 1944-46. 
Antonio Cassese of the International Criminal Tribunal for the former Yugoslavia once compared the pre-and post-World War II roles of sovereignty and human rights in the international community. He wrote that prior to World War II, "[t]he international community was truly a juxtaposition of subjects, each concerned only with its own well-being and its freedom of manoeuvre... [and individuals were] absorbed and overshadowed by the 'princes': the sovereign states, the only real actors on the world stage."27 The postwar system, he wrote, maintained the same structure and still recognized sovereign states as the "true holders of power," but that the doctrines of human rights and self-determination "have introduced seeds of subversion into this framework, destined sooner or later to undermine and erode the traditional structures and institutions, and gradually-over a very broad space of time, the course of which cannot yet be foreseen-to revolutionize those structures and institutions."28

Today's post-World War II human rights movement largely relies on international institutions for its progress..$^{29}$ As the following Section illustrates, the UN has filled a central role in the international commumity and the international human rights movement. ${ }^{30}$ Thus, the UN has both the obligation to promote and protect human rights.

\section{B. The Role of the United Nations in Promoting and Protecting Human Rights}

The UN, at its inception after World War II, offered the first authoritative expression of a commitment to international human rights ${ }^{31}$ in its Charter. ${ }^{32}$ The Charter did not set forth concrete examples of human rights; rather, it pledged the UN to encouraging, promoting, and respecting human rights. ${ }^{33}$ The UN subsequently has played an important role in the progress of international human rights; concern for these rights has gained

27. CASSESE, supra note 17, at 13.

28. Id. at 23.

29. See Henry J. Steiner \& Philip Alston, International Human Rights in Context 118 (1996).

30. See Gareth Evans, Cooperating for Peace 170 (1993).

31. For purposes of this Comment, the terms "international human rights" and "universal human rights" are used interchangeably.

32. See STEINER \& ALSTON, supra note 29, at 118. The Charter repeatedly makes reference to human rights, including references in the second paragraph of its Preamble, Article 1, Paragraph 3; Article 13, Paragraph 1(b); Articles 55; Article 56; Article 62, Paragraph 2; and Article 68. See id. at 118-19. The UN Charter Preamble states that the People of the UN determined to save succeeding generations from the scourge of war ... to reaffirm faith in fundamental human rights, in the dignity and worth of the human person, in the equal rights of men and women and of nations large and small ... to promote social progress and better standards of life in larger freedom ... [and] have resolved to combine our efforts to accomplish these aims.

U.N. ChaRTER preamble.

33. See U.N. ChaRTER preamble. 
increasing prominence within the UN over the past fifty years. ${ }^{34}$ However, a dichotomy exists between the UN's institutional policies regarding huinan rights and the practices of its meinber states. As Professor Bruno Simma stated,

Huinan rights in the UN are not only a success story of legal activism, a professional growth industry and the favorite language in which to couch your clain of the day, but also a hotbed of hypocrisy, double standards and doublespeak-here we have probably the field of UN activity in which the discrepancy between words and deeds is inost notorious. ${ }^{35}$

This picture of the UN concludes with the reminder that the international community is "miles away from a truly effective systen of actual protection of human rights." ${ }^{36}$ The truth of Professor Simma's cynical view is undeniable. Political reality inspires such hypocrisy; neinber states want the benefits of looking politically correct while still protecting their sovereign interests, which often clash with international human rights norms. This reality, however, only serves to underscore the conclusion reached by the UN Under-Secretary-General for Human Rights in 1993 that "the challenge to the international community to promote and ensure respect for hunian rights is no less essential today than it was in 1945, nor is it any less relevant to the preservation of peace; rather to the contrary." 37

In response to the UN's efforts to protect human rights, states have charged the UN with violating Article 2, Paragraph 7 of the UN Charter. ${ }^{38}$ Article 2, Paragraph 7 provides that "[n]othing contained in the present Charter shall authorize the United Nations to intervene in matters which are essentially within the domestic jurisdiction of any state...."39 This condition brings into conflict state sovereignty and the UN's ability to restrain that sovereignty in the area of human rights. ${ }^{40}$ Most international scholars agree that the forward progress of human rights has constrained the ability of states to hide behind Article 2, Paragraph 7 and the defense of domestic jurisdiction. ${ }^{41}$ The General Assembly has interpreted Article 2, Paragraph 7 narrowly to permit debate and the adoption of resolutions

34. See Simma, supra note 17 , at 263.

35. Id. at 264.

36. Id.

37. Jan Martenson, The United Nations and Human Rights Today and Tomorrow, in HUMAN Rights in the TwENTY-First Century 925, 928 (Kathleen E. Mahoney \& Paul Mahoney eds., 1993).

38. See Steiner \& ALston, supra note 29, at 163-64; Simma, supra note 17, at 266.

39. U.N. ChARTER art. 2, para. 7.

40. See SteINER \& ALSTON, supra note 29, at 163.

41. See OTr, supra note 11, at 247; Robert McCorquodale, Human Rights and Self-Determination, in THE NEW WORLD ORDER 12 (Mortimer Scllers ed., 1996); Simma, supra note 17, at 266; Reisman, supra note 26, at 158 (asserting that "no serious seholar still supports thc contention that internal human rights are 'essentially within the domestic jurisdiction of any statc' and hence insulated from international law”). 
regarding member states' human rights violations. ${ }^{42}$ Even Professor Simma, though critical of the UN's hypocrisy regarding human rights, admits that it is safe to consider "the entitlement of the UN to respond to violations of human rights ... to be firmly established in present customary international law."43

Some scholars assert that the current UN system is madequate to meet the challenges of the modern international community, making reform necessary for the UN to meet its goals ${ }^{44}$ and maintain legitimacy. ${ }^{45}$ The continuing shift in the international community toward protecting human rights also mandates structural changes within international institutions such as the UN; such institutional change is inherently difficult to achieve. ${ }^{46}$ In light of this difficulty, the UN's actual progress over just the past fifty years is significant. ${ }^{47}$ The imcreasing importance of human rights within the international community, as discussed in Part I.A., makes further fundamental change possible. Representatives to the UN may well try to shape international policies to conform with their states' political agendas. However, they must be continually reminded that "they cannot expect international organizations to serve them well, now or im the future, if their urge to exploit these institutions for immediate political advantage overrides all consideration"48 of the proper developnient of the UN's imstitutional procedures. The UN will remain a political institution, ${ }^{49}$ filled with individuals advocating political goals. Instead of allowing those individuals to mamipulate the process at will, however, the UN's procedural structure should provide a steadfast framework for mandatory consideration of hunian rights issues..$^{50}$ Political interest still may influence that framework, but changing UN procedure to include consideration of human rights is a

42. This occurred with the condemnation of apartheid in South Africa. See STEINER \& AlsTON, supra note 29, at 164; see also OTr, supra note 11, at 247.

43. Simma, supra note 17 , at 266; see also STEINER \& ALSTON, supra note 29, at 164 (concluding that in overriding domestic jurisdiction arguments, the UN has possibly created new law on the human rights question in relation to Article 2, Paragraph 7).

44. See Ibrahim J. Gassama, World Order in the Post-Cold War Era: The Relevance and Role of the United Nations After Fifty Years, 20 Brook. J. INT'L L. 255, 260 (1994) (addressing the inadequacies of the current UN system in meeting its objective of saving succeeding generations from the scourges of war).

45. See Trimble, supra note 11 , at 1969 (noting that international institutions generally must be "significantly reformed" to achieve legitimacy in modern globalization).

46. See David D. Caron, The Legitimacy of the Collective Authority of the Security Council, 87 AM. J. INT'L LAw 552, 556 (1993).

47. For a concise overview of UN steps taken to meet its Charter goals of mandating respeet for human rights, see CASSESE, supra note 17, at 195-97.

48. INIS ClAUde, Swords INTo Plowshares 6 (4th ed., 1984), reprinted in STEINER \& ALSTON, supra note 29 , at 336,337 .

49. See supra note 9 (discussing the political nature of the UN).

50. The Accreditation Proposal provides this procedural framework within the credentials verification and accreditation process. See discussion infra Part III. 
necessary first step in the gradual process of making the UN's philosophical commitment to international human rights into a political reality.

In the end, however, UN debates, resolutions, and even direct action cannot achieve lasting protection for human rights in a member state. Only the state's own government and legal system can truly achieve a stable and long-term respect for human rights. ${ }^{51}$ The UN Under-Secretary-General for Human Rights acknowledged this truth in asserting that the international community "must recognize its obligation to assist in creating conditions within which these [human rights] standards can be fulfilled." 52 The Under-Secretary-General stated that it is the UN's responsibility to

further develop its capacity to identify human rights violations at an early stage and to act effectively to bring them to an end. We may also wish to explore ways in which governments can be encouraged-when necessary-to be more responsive to the requests, suggestions and recommendations of United Nations human rights bodies.... ${ }^{53}$

The UN has the power to encourage governments to be more responsive to human rights law through its collective acts and decisions because it can hurt the violating state by withholding aid or restricting relations between UN member states and the violator. ${ }^{54}$ Through such actions, an international institution "becomes the bridge between states (the very creators of international norms) and the norms themselves. It can make those norms 'real."'s5 One very practical way in which the UN could advance the human rights goals it has long espoused is through reforming its accreditation process. By considering the human rights records of rival governments claiming to represent a member state, the UN should send a very clear message to new governments: If you violate the human rights of your citizens, we may decide that you do not really represent them.

\section{II}

REPRESENTATION IN THE UNITED NATIONS: A Critique of the Existing Accreditation Process

\section{A. The UN Weaves a Tangled Web of Representation and Accreditation}

To state the obvious, the practical functioning of a real-world institution like the UN requires that specific individuals represent its incorporeal "member states," speaking and voting on behalf of those states in the

51. See Simma, supra note 17, at 269.

52. Martenson, supra note 37, at 926.

53. Id. at 928 .

54. See Steiner \& Alston, supra note 29 , at 335-36.

55. Id. at 336. 
General Assembly and in other UN organs. ${ }^{56}$ Those individuals form delegations for each member state and must be accredited before they can take their seats in the General Assembly. ${ }^{57}$ Each member state specifies the members of its delegation through official credentials prior to the start of each new session in September. ${ }^{58}$ The delegation then submits its credentials for verification and approval to the Credentials Committee. ${ }^{59}$ The General Assembly appoints this committee, consisting of nine member states, at the beginning of each session. ${ }^{60}$ The Credentials Committee's basic mandate is to examine each representative's credentials and to report on their validity to the General Assembly. ${ }^{61}$ This Credentials Committee report makes recommendations to the General Assembly on whether to accept each representative's credentials. ${ }^{62}$ The accreditation of a representative is complete when the General Assembly accepts the Credential Committee's recommendation. ${ }^{63}$

Rule 27 of the UN Rules of Procedure provides:

The credentials of representatives and the names of members of a delegation shall be submitted to the Secretary-General if possible not less than one week before the opening of the session. The credentials shall be issued either by the Head of the State or Government or by the Minister for Foreign Affairs. ${ }^{64}$

The drafters of the Rules of Procedure designed the accreditation process to be purely procedural. Once the Credentials Committee verifies that the credentials meet the criteria of Rule 27, it reports this verification to the General Assembly, which then decides whether to accept the representative. ${ }^{65}$ Thus, the rule offers no basis for a substantive evaluation of the

56. The United Nations as a whole is comprised of many different groups, called bodies or organs. The Security Council and General Assembly are perhaps the most well-known of these bodies, but in addition to these there are numerous committees, councils, programs, and specialized agencies, often called subsidiary bodies or organs. See generally UNITED NATIONS HANDBOOK 1997, supra note 5 (describing the structure and functions of UN organs).

57. See Rules of Procedure of the General Assembly, Rules 25-29, U.N. Doc. A/520/Rev.15 (1985) [hereinafter General Assembly Rules of Procedure].

58. See id. Rules 25-27. Rule 25 states: "The delegation of a Member shall consist of not more than five representatives and five alternative representatives and as many advisers, technical advisers, experts and persons of similar status as may be required by the delegation." Id. Rule 25.

59. See id. Rule 27.

60. See id. Rule 28.

61. See id.

62. See General Assembly Rules of Procedure, supra note 57, Rule 27. Rule 65 further provides that "[t]he General Assembly shall not, unless it decides otherwise, make a final decision upon any item on the agenda until it has received the report of a committee on that item." Id. Rule 65.

63. The General Assembly can accept, reject, or postpone decision on the Credentials Committee's recommendation through consensus without a vote, see General Assembly Rules of Procedure, supra note 57, Annex V, at II 204, or by a simple majority vote, see id. Rule 85; UNITED NATIONS HANDBOOK 1997, supra note 5, at 11.

64. General Assembly Rules of Procedure, supra note 57, Rule 27.

65. See id. Rules 28-29. 
delegation. Generally speaking, most member states submit only one delegation and one set of credentials when applying for accreditation. For most states, then, the existing accreditation process works efficiently. Once a delegation is accredited, it represents the state in the UN. ${ }^{66}$ Problems arise, however, when rival governments within a member state submit more than one set of credentials to the Credentials Committee. The current structure of the accreditation process does not provide adequate guidelines to determine the issue of representation when it arises, as it infrequently, yet consistently, does. ${ }^{67}$ This Comment will analyze precisely this problem in Part IV's case study of the UN's three representation disputes involving Cambodia.

Though the distinction between accreditation and representation may be stated categorically on paper, the credentials verification process maintains, in reality, an underlymg substantive aspect directly linked to the right of representation. Verification of credentials is techmically procedural, but the act of accrediting a delegation implicitly affords some degree of approval to the government offering that delegation. ${ }^{68}$ The UN may continue to deny the existence of this substantive aspect of the accreditation process, but in practice, most member states "have looked beyond the façade of credentials to the legitimacy of the authority issuing them." 69

Some international law scholars question the wisdom of allowing the issue of representation to be decided within the procedural context of credentials verification. ${ }^{70}$ These scholars raise valid concerns relating to the use of the credentials verification process to resolve representation disputes. Their arguments mclude claims that the issue of representation is too important to entrust to the nine members of the Credentials Committee, and that representation is an "important question" which the General Assembly should decide by a two-thirds majority vote under Article 18 of the UN Charter. ${ }^{71}$ Further, it is procedurally confusing to use the same set of rules in deciding both the substantive, important issue of representation and in procedurally verifying credentials. ${ }^{72}$ The problem with combining representation disputes and credentials verification becomes clear "when

66. See supra note 8 (explaining the difference between "accreditation" and "representation").

67. See supra Introduction.

68. See Hans Kelsen, The Law of The United Nations 947 (1950).

69. Jhabvala, supra note 8 , at 621 .

70. For criticism of use of the credentials process to decide issues of representation, see Rosalyn Higgins, The Development of International Law Through the Political Organs OF THE UNITED NATIONS 151-52 (1963); Dan Ciobanu, Credentials of Delegations and Representation of Member States at the United Nations, 25 INT'L \& CoMP. L.Q. 351, $372-73$ (1976); Jhabvala, supra note 8 , at 623 .

71. See Higans, supra note 70, at 150-51; see also UN CHARTER art. 18, para. 2 ("Decisions of the General Assembly on important questions shall be made by a two-thirds majority of the members present and voting.").

72. See Jhabvala, supra note 8 , at 623 . 
one compares the scant importance that the General Assembly has attached to credentials, by accepting them late and in improper forms, with the bitter debates over representation issues; one logically may conclude that actions taken on credentials are of a different type than those taken on representation." 73

These concerns merit attention. The credentials verification process may not be the ideal forum for dealing with issues of representation. However, neither the UN Charter nor the Rules of Procedure include specific rules pertaining to the issue of representation. The UN Charter contains a "gap" when it coines to dealing with disputes over representation arising when unconstitutional or revolutionary changes in government occur within member states. ${ }^{74}$ No distinct UN forum exists to deal with representation disputes; theoretically, governments may raise disputes within any UN organ.

The Credentials Committee ultimately becomes involved in determining representation for the practical reason that it is responsible for accrediting delegations for the General Assembly. The Committee automatically addresses disputes when multiple sets of credentials are submitted. The General Assembly later becoines involved when discussing whether to approve the Credential Cominittee's report. Even when a government successfully raises a representation dispute directly before the General Assembly, the Assembly may postpone a decision ${ }^{75}$ or refer the dispute to the Credentials Cominittee for its recommendation. ${ }^{76}$ Thus, the accreditation process provides a practical starting point for representation disputes between rival governments, which may then continue within the General Assembly. Further, the UN Legal Counsel has expressly stated that the credentials process is an appropriate forum to deal with representation issues when rival governments concurrently claim authority for a single state. ${ }^{n}$

Regardless of the forum, consistent resolution of representation disputes requires specific guidelines. The next Section docuinents the spectrum of criteria and guidelines that the UN has considered as tools for deciding representation disputes. Despite alnost fifty years of discussion on this topic, the General Assembly has failed to achieve a clear procedure

73. Id. at 623-24.

74. See id. at 618; see also HrGGINs, supra note 70, at 132 .

75. In 1973, the General Assembly separately addressed a representation dispute in Cambodia, but postponed resolution of the issue until the Credentials Committee issued its report, which the General Assembly then approved. See U.N. GAOR, 28th Sess., 2191st plen. mtg. I 181, at 18-19, U.N. Doc. A/PV 2191 (1973); U.N. GAOR, 28th Sess., 2204th plen. mtg. at 4, U.N. Doc. A/PV/2204 (1973); G.A. Res. 3181 (XXVIm) (1973).

76. See infra Part IV.B.2 (discussing the 1979 Cambodian dispute in which the General Assembly referred the representation dispute to the Credentials Committee for consideration).

77. See U.N. GAOR, 25th Sess., Annexes, Agenda Item 3, at 3, U.N. Doc. A/8160 (1970) [hereinafter UN Legal Counsel's Opinion]. 
for this process. The guidelines ultimately adopted and currently in use are ambiguous and insufficient to enable either the Credentials Committee or the General Assembly to produce consistently derived decisions on representation issues. Examination of the evolution of the current accreditation process illustrates those insufficiencies and provides the foundation for the Accreditation Proposal in Part III.

\section{B. Evolution of the Procedure for Resolving Representation Disputes}

Just five years after the inception of the United Nations, the General Assembly faced its first debate about representation in the context of rival governments. A Chinese representation dispute arose after Mao Ze Dong successfully took control of mainland China in $1949 .{ }^{78}$ Mao's victory forced the Kuomintang Nationalist Government headed by Chiang Kai Shek onto the island of Taiwan, where it continued to proclaim itself the legitimate authority of China. Sharp disagreement arose over which government the UN should accept as China's representative. ${ }^{79}$ In a letter to the President of the Security Council, India's representative raised the undesirable possibility that different UN organs might reach conflicting results as to which government should represent China unless the UN established "[s]ome uniform procedure, which can be adopted by all the organs." 80

The Secretary-General produced a memorandum on the legal aspects of representation in response to the Indian representative's request. ${ }^{81}$ This memorandum is one of three major attempts over the past fifty years to bring order to the chaos of the representation issue within the credentials process. ${ }^{82}$ The two other major attempts are the General Assembly Resolution 396(V) $)^{83}$ and an opimion by UN Legal Counsel on the "Scope of 'Credentials' in Rule 27."84 Together, these three documents introduce the full spectrum of criteria the UN has considered for the resolution of

78. For a further discussion of the Chinese representation dispute, see HigGins, supra note 70, at 150-58; Roth, supra note 6, at 420-24; Yuen-Li Liang, Notes on Legal Questions Concerning the United Nations: Recognition by the United Nations of the Representation of a Member State: Criteria and Procedure, 45 AM. J. INT'L L. 689 (1951).

79. The United States opposed Mao's communist government, while the USSR challenged continued representation by the Kuomintang delegation. See Thomas M. Franck, The PoWer of LEGITIMACY AMONG NATIONS 738 (1990); Liang, supra note 78, at 691.

80. U.N. SCOR, 5th Sess., Supp. for Jan.-May 1950, at 2, U.N. Doc. S/1447 (1950). Though the United States was successful in blocking the new Communist government from becouning China's representative, the General Assembly in 1971 recognized the Communist delegation as China's representative in the General Assembly. See Brad R. Roth, Governmental Illegitimacy Revisited: 'ProDemocratic' Armed Intervention in the Post-Bipolar World, 3 TRANSNAT'L L. \& ConTeMP. Probs. 481, 495 (1993).

81. See U.N. SCOR, 5th Sess., Supp. for Jan.-May 1950, at 18, U.N. Doc. S/1466 (1950) [hereinafter UN Secretary-General's Memorandum].

82. See Jhabvala, supra note 8, at 624 .

83. G.A. Res. 396(V), U.N. GAOR, 5th Sess., Supp. No. 20, at 24-25, U.N. Doc. A/1775 (1950) [hereinafter General Assembly Resolution 396(V)].

84. UN Legal Counsel's Opinion, supra note 77, at 3. 
representation disputes. For a resolution of current representation disputes, Resolution 396(V), which the General Assembly voted into existence in December $1950,{ }^{85}$ logically would supersede the Secretary-General's memorandum written im March $1950{ }^{86}$ The Legal Counsel's Opinion, following the adoption of Resolution 396(V), may be seen as providing supplemental guidance in applying Resolution 396(V). Regardless of the pecking order of these documents, none of these attempts successfully eliminated inconsistency and uncertainty in resolving $\mathrm{UN}$ representation disputes.

\section{Secretary-General's Memorandum on "The Legal Aspects of the Problem of Representation in the United Nations" 87}

The Secretary-General's memorandum noted that the issue of Chinese representation was "unique ... not because it involves a revolutionary change of government, but because it is the first in which two rival governments exist. ${ }^{28}$ The memorandum noted that though recognition was not a collective act, the issue of representation was "clearly determined by a collective act of the appropriate organs ... in the case of representation, by vote of each competent organ on the credentials of the purported representatives." ${ }^{89}$ Thus, the Secretary-General left it to each individual UN organ $^{90}$ to resolve representation disputes.

The Secretary-General proposed that when two rival governnients claimed to be the true representative of a member state, the issue should be "which of these two governments in fact is in a position to employ the resources and direct the people of the State in fulfillment of the obligations of membership." 91 The Secretary-General gave the criterion an objective tone by adding that "[i]n essence, this means an inquiry as to whether the new government exercises effective authority within the territory of the State and is habitually obeyed by the bulk of the population." 92 This inquiry became known as the "effective control" test.

The Secretary-General's test was to be apphied uniformly, but the test in itself is inadequate to deal with representation disputes in the modern international community. The seeining siniplicity of the effective control test does not eliminate the possibility that different groups of individuals inight reach different conclusions about which government maintains effective control of a region. Leaving resolution of representation disputes to

\footnotetext{
85. See General Assembly Resolution 396(V), supra note 83, at 25 .

86. See UN Secretary-General's Memorandum, supra note 81, at 18.

87. Id.

88. Id. at 22 .

89. Id. at 20 .

90. See supra note 56 (describing the various organs of the UN).

91. UN Secretary-General's Memorandum, supra note 81, at 23.

92. Id.
} 
the various UN organs creates potential confusion if different organs reach different decisions. Further, the effective control test does not take into account substantive issues of representation, such as human rights and the willing consent of the people to a particular government's control. ${ }^{93}$ While the effective control test is a valuable factor to consider, it is insufficient by itself to determine representation.

\section{Resolution 396(V): "Recognition by the United Nations of the representation of a Member State" 94}

During its fifth session, in 1950, the General Assembly included the issue of representation on its agenda under the heading "Recogmition by the United Nations of the representation of a Member State."95 The Assembly referred the item to the Ad Hoc Political Committee ${ }^{96}$ for a report on the proper evaluation of a representative's credentials. ${ }^{97}$ Recognizing that "it is in the interest of the proper functioning of the [UN] that there should be umformity in the procedure applicable when there are doubts regarding the representation of a Member State,"98 various draft resolutions for standardized evaluation were submitted to the Ad Hoc Political Committee. These draft resolutions included the submissions of individual delegations' proposals recommending guidelines that the General Assembly should adopt. The Ad Hoc Political Committee voted to adopt its own draft resolution containing elements of several submissions. A detailed analysis of the criteria suggested in these resolutions is necessary to show the full spectrum of potential factors available for determining representation disputes. This analysis also reveals the inadequacies of the resolution that the General Asseinbly finally adopted, which is both sparse and vague in comparison to the draft resolutions submitted to the Ad Hoc Political Committee.

93. See infra Part III (discussing the relation of these substantive issues to the Accreditation Resolution).

94. General Assembly Resolution 396(V), supra note 83, at 1 .

95. U.N. GAOR, 5th Sess., Annexes, Agenda Item 61, at 1 (1950).

96. The Ad Hoc Political Committee is one of the General Assembly's subsidiary bodies that can be used to provide in-depth or expert recommendations to the General Assembly. See UNITED Nations HANDBOOK 1997, supra note 5, at 26-43.

97. The decision to refer the item to the political committee came after the General Asscmbly received two letters from the Cuban delegation requesting that the Fiftl Assembly consider the recognition issue, see U.N. GAOR, 5th Sess., Annexes, Agenda Item 61, at 1-2, U.N. Docs. A/1292 \& A/1308 (1950), and a letter to the Secretary-General from the United Nations Educational, Scientific, and Cultural Organization (UNESCO) requesting that the UN adopt general representation criteria to settle problems where multiple authorities claim to be the government of a member state, see U.N. GAOR, 5th Sess., Annexes, Agenda Item 61, at 3, U.N. Doc. A/1344 (1950).

98. U.N. GAOR Ad Hoc Political Comm., 5th Sess., Annexes, Agenda Item 61, at 5, U.N. Doc. A/AC.38/L.6 (1950) [hereinafter Cuban Draft Resolution]; see also U.N. GAOR Ad Hoc Political Comm., 5th Sess., Annexes, Agenda Item 61, at 6, U.N. Doc. A/AC.38/L.21 (1950) thereinafter U.K. Draft Resolution]. 


\section{a. Draft Resolutions Preceding Resolution 396(V)}

Cuba submitted the only draft resolution which included explicit consideration of human rights in evaluating the representation of a Member State. The Cuban resolution listed four factors to consider in deciding the question of representation: "(a) Effective authority over the national territory; (b) The general consent of the population; (c) Ability and willingness to achieve the purposes of the Charter, to observe its principles and to fulfil international obligations of the State; and (d) Respect for human rights and fundamental freedoins." 99

China, still represented by the Kuomintang delegation, submitted an amendinent to the Cuban resolution which proposed additional language for each of the four factors. The new langnage required effective authority to be "established without the intervention of any other State, independent of foreign control and domination, and not as a result of foreign aggression, direct or indirect." ${ }^{100}$ The amendinent specified that "general consent of the population" must be achieved through "freely conducted or internationally supervised or observed elections." 101 Further, the amendinent suppleinented the required ability and willingness to fulfill Charter and international obligations with a prohibition against "acts of aggression" or compliance with UN-proclaimed "aggressors." 102 Finally, the amendinent adopted the UN Universal Declaration of Human Rights to define human rights and fundamental freedoms. ${ }^{103}$ Both the Cuban and Chinese resolutions would have referred the question of representation to the General Assembly for decision. ${ }^{104}$

The United Kingdoin submitted a very different draft resolution which paralleled the Secretary-General's effective control test. ${ }^{105}$ The British resolution based a particular government's right to represent the nnember state on three requirements. First, the government must exercise effective control and authority over nearly all the State's territory. ${ }^{106}$ Second, the government must have the "obedience of the bulk of the popnlation." ${ }^{107}$ Finally, the control, authority, and obedience inust at least appear to be pernanent. ${ }^{108}$ The origmal U.K. resolution referred questions regarding representation to the General Assembly, while leaving the other

99. Cuban Draft Resolution, supra note $98, \mathbb{1} 1$, at 5 .

100. U.N. GAOR Ad Hoc Political Comm., 5th Sess., Annexes, Agenda Item 61, II 2, at 6, U.N. Doc. A/AC.38/L.22 (1950) [hereinafter Chinese Amendment].

101. Id.

102. Id.

103. See id.

104. See Cuban Draft Resolution, supra note 98, I 2, at 5; Chinese Amendment, supra note 100, II

2 , at 6.

105. See U.K. Draft Resolution, supra note 98, at 6 .

106. See id. I 1 , at 6 .

107. Id.

108. See id. 
UN organs free to make necessary decisions on an interim basis. The resolution, however, recommended that other UN organs and specialized agencies ultimately adopt the General Assembly's decision. ${ }^{109}$ The U.K. later submitted a revised resolution which deleted the referral to the General Assembly. ${ }^{110}$ Instead, it recommended that the various organs and specialized agencies within the UN should themselves apply the effective control test when questions regarding representation arose. ${ }^{\text {II }}$ Veneznela proposed an amendment to the U.K. resolution requiring that the government in question "expressly declare[] its willingness to fulfil the international obligations of the State."112

Approaching the issue in an entirely different manner, the Dominican Republic submitted a draft resolution reqnesting further study before the General Assembly adopted any resolution on determining representation disputes. ${ }^{113}$ The draft resolution specified that the General Assembly request a special study by the International Law Commission on the legal aspects of the representation issue, and that the General Assembly postpone its consideration of the other draft resolutions in the interim. ${ }^{114}$

\section{b. The Adoption of Resolution 396(V)}

Upon receiving the various resolutions, the Ad Hoc Political Committee established a subcommittee to consider them and make a recommendation on the appropriate criteria for evaluating representation disputes. ${ }^{115}$ The subcommittee adopted a draft resolution ${ }^{116}$ recommending that when representation "becoines the subject of controversy in the United Nations, it should be considered in the light of the purposes and principles of the Charter and the circnmstances of each case." 117 The report listed

109. See id. T3 3 , at 6.

110. See U.N. GAOR Ad Hoc Political Comm., 5th Sess., Annexes, Agenda Item 61, at 8, U.N. Doc. A/AC.38/L.21/Rev.1 (1950) [hereinafter U.K. Revised Draft Resolution].

111. See id. $\mathbb{2}$, at 8.

112. U.N. GAOR Ad Hoc Political Comm., 5th Sess., Annexes, Agenda Item 61, at 7, U.N. Doc. A/AC.38/L.24 (1950).

113. See U.N. GAOR Ad Hoc Political Comm., 5th Sess., Annexes, Agenda Item 61, at 7, U.N. Doc. A/AC.38/L.23 (1950).

114. See id. In 1957, the General Assembly established the International Law Commission, made up of thirty-four individual experts who are not representatives of governments, to "promote the development and codification of international law." AMOS Yoder, THE Evolution OF THE UNITED NATIONS System 120 (3d ed. 1997).

115. The subcommittee was composed of the representatives of Australia, Belgium, China, Cuba, Denmark, the Dominican Republic, Egypt, France, India, Turkey, the United Kingdom, the United States, Uruguay, and Venezuela. See Report of Sub-Comm. 2 to the Ad Hoc Political Comm., U.N. GAOR Ad Hoc Political Comm., 5th Sess., Annexes, Agenda Item 61, II 1, at 8, U.N. Doc. A/AC.38/L.45 (1950).

116. The vote was eight in favor (Australia, Belgium, China, Cuba, Denmark, Egypt, the United States, and Uruguay), four against (the Dominican Republic, France, India, Venezuela), and two abstentions (Turkey and the United Kingdom). See id. T1 9, at 9.

117. Id. 
several factors to be included in the determination, including effective control of territory, general acceptance by the population, willingness to carry out Charter obligations, and the extent to which the authority in question came to power through "internal processes." 118 Finally, the resolution recommended that the General Assembly consider representation disputes and that other UN organs take its decision into account. ${ }^{119}$

The Ad Hoc Political Committee adopted the subcommittee's resolution only after the subcommittee deleted the paragraph containing specific factors for consideration. ${ }^{120}$ In explaining their votes on the resolution, several meinber states expressed concern that the list of factors might mistakenly be interpreted as exclusive rather than illustrative. ${ }^{121}$ The resolution that the Ad Hoc Political Committee submitted to the General Assembly recommended only that when representation "becomes the subject of controversy in the United Nations, the question should be considered in the light of the purposes and principles of the Charter and the circumstances of each case," and that the General Assembly's "attitude" on the matter should be "taken into account in other organs."122

The General Assembly adopted the draft proposal of the Ad Hoc Political Committee with the passage of Resolution 396(V). ${ }^{123}$ Two

118. Id.

119. See id. I 9, at 10. The draft resolution would not make the General Assembly's decision binding on other UN organs; thus, the draft resolution inevitably would fail to eliminate the "risk" expressed in its opening paragraph that "conflicting decisions may be reached by [the UN's] various organs." Id. II 9 , at 9.

120. The altered draft resolution was adopted by a vote of twenty-seven in favor (Afghanistan, Argentina, Brazil, Burma, Byelorussia, Czechoslovakia, the Dominican Republic, Ecuador, Egypt, France, India, Indonesia, Israel, Mexico, Norway, Pakistan, Poland, Saudi Arabia, Sweden, Turkey, Ukraine, South Africa, the USSR, the United Kingdom, Venezuela, Yemen, and Yugoslavia), thirteen against (Australia, Belgium, Chile, China, Cuba, Guatemala, Honduras, Iraq, New Zealand, Paraguay, Thailand, the United States, and Uruguay), and fourteen abstentions (Canada, Colombia, Denmark, El Salvador, Ethiopia, Greece, Haiti, Iran, Lebanon, the Netherlands, Panama, Peru, the Philippines, and Syria). See Report of the Ad Hoc Political Comm., U.N. GAOR, 5th Sess., Annexes, Agenda Item 61, I 19, at 15, U.N. Doc. A/1578 (1950). It is interesting to note that several states switched from their positions in the subcommittee: Australia and the United States voted for the resolution in the subcommittee but against the resolution in the Ad Hoc Political Committee, and the Dominican Republic switched from a vote against the resolution to a vote in favor of the resolution in the Ad Hoc Political Committee. No explanation was given for the changes in position, but it secms likely the decisions were related to the deletion of the paragraph listing specific factors to consider in determining representation.

121. Australia noted that its delegation supported the draft resolution because it agreed with the general approach, but made clear that "no enumeration of criteria was exhaustive and each case should be dealt with on its merits." Id. I 30, at 11. The Dominican Republic delegation felt compelled to vote against the draft resolution without additional study and consideration of the factors involved, and asserted that it "did not consider that the Subcommittee could solve the problem of representation in the General Assembly by enumerating only a few of the factors involved." Id. I33, at 11.

122. Id. I 21, at 16. As with the subcommittee's draft resolution, the draft resolution the Ad Hoc Political Committee submitted to the General Assembly did not make the General Assembly's decision binding on other UN organs.

123. General Assembly Resolution 396 (V), supra note 83. 
changes accompanied the passage: inclusion of a paragraph recommending that the General Assembly should consider any question of representation and the capitalization of the words "Purposes and Principles." 24

\section{c. The Deficiencies in Resolution 396(V)}

Resolution $396(\mathrm{~V})$ is far too vague to address sufficiently the important question of representation. One key reason the discussion of representation arose in the first place was the "danger that conflicting decisions on this subject inay be reached by the various organs of the Uinited Nations and in the Specialized Agencies." 225 Yet even with the inclusion of the paragraph recommending consideration by the General Assembly, Resolution 396(V) does not make the General Assembly's decision on representation binding on other UN organs. The Assenbly's decision must simply be "taken into account." Thus, there reinains the possibility that some UN organs might recognize a new government, while others refuse recognition, regardless of the General Asseinbly's decision on the matter. ${ }^{126}$

The Resolution does not contain any specific criteria beyond the reference to the UN Charter's "Purposes and Principles" to help the General Asseinbly in its determination. The capitalization of the terms inplies a reference to Chapter I of the Charter, which is also entitled "Purposes and Principles." 27 Article One of the Charter lists the "Purposes" of the UN, which include "friendly relations among nations based on respect for the principle of equal rights and self-determination of peoples" and "proinoting and encouraging respect for human rights and for fundamental freedoins for all." 128 The self-determination requirement could be equated with the Cuban resolution's "general consent of the population" requireinent; the Cuban resolution also uses the same "human rights and fundamental freedoms" language as that fouud in the Charter. ${ }^{129}$

Article Two lists the "Principles" of the UN which include "fulfil[ing] in good faith the obligations ... in accordance with the present Charter."130 This principle is similar to the Cuban resolution requirentent that the new government be able and willing to ineet the obligations of the Charter. ${ }^{131}$

124. U.N. GAOR, 5th Sess, 325th plen. mtg., Agenda Item 61, III 141-142, at 675, U.N. Doc. A/PV.325 (1950).

125. U.K. Draft Resolution, supra note 98 , at 6.

126. See KELSEN, supra note 68 , at 948.

127. This implication was acknowledged in a statement by China's representative that the Resolntion "gives primary importance to the principles and purposes of the Charter as guiding considerations in the determination of the question of representation." U.N. Doc. A/PV.325, supra note 124 , प1 168, at 677 .

128. U.N. Charter art. 1.

129. Cuban Draft Resolution, supra note 98, at 5.

130. U.N. ChARTER art. 2.

131. See Cuban Draft Resolution, supra note 98 , at 5. 
Very similar language is also found in Article Four of the UN Charter, which states requirements for UN membership. ${ }^{132}$

Most of the specific criteria proposed in the draft resolutions closely resemble the "Purposes and Principles" histed in the UN Charter, yet these criteria are absent from Resolution 396(V). Thus, the question arises whether these specific criteria are excluded froin general analysis under Resolution 396(V), or whether they are included indirectly under the auspices of "Purposes and Principles" of the UN Charter. In addition, the objective "effective control" test does not appear in the text of Resolution $396(\mathrm{~V})$, though it played an important role in the previous draft resolutions. ${ }^{133}$ Though the effective control test by itself is not sufficient to determine representation, it remains an important consideration in the overall determination of representation. The government with effective control over the member state's territory and people has the actual power necessary to make enforceable decisions for the member state in the international community. Thus, the presence or absence of this power is an essential component of any representation debate. ${ }^{134}$

It is unclear how the explicit rejection of specific criteria is to be reconciled with the guidance of the "Purposes and Principles" of the UN Charter under Resolution 396(V). The ambiguities of Resolution 396(V) are demonstrated through analysis of actual representation disputes arising since $1950 .{ }^{135}$ Discrepancies exists between the adopted text of Resolution 396(V) and the discussions undertaken in resolving actual representation disputes. Such analysis highlights the need for more definite criteria to guide representation evaluations and to deter nember states froni using the credentials process to achieve individual political goals. ${ }^{136}$

132. See U.N. Charter art. 4, para. 1 ("Membership in the United Nations is open to all other peace-loving states which accept the obligations contained in the present Charter and, in the judgment of the Organization, are able and willing to carry out these obligations.").

133. See OTT, supra note 11, at 88 (arguing that the "pro-American" General Assembly "rejected" the United Kingdom's objective test and ultimately adopted the American view of looking at each case subjectively). It is possible, though unlikely, that Resolution 396(V) excludes the effective control test because the Secretary-General's letter, discussed in Part II.B.1, already adopted the test. However, there is no indication that the two documents are intended to apply concurrently, so such an assumption will not be made here.

134. The Credentials Committee and General Assembly have considered the effective control test in actual representation disputes. See infra Part IV.A discussing the 1973 Cambodian representation dispute. As this Comment argues in Part III.B.1, the accreditation process should always consider which government maintains effective control in determining representation disputes.

135. Though this Comment's analysis of credentials disputes focuses solely on Cambodian case studies, several commentators' discussions of other credentials disputes support the assertion that Resolution 396(V) does not accurately reflect the scope of many past credentials disputes. See BLuM, supra note 6, at 33-56; RoTH, supra note 6, at 420-54; Malvina Halberstain, Excluding Israel from the General Assembly by a Rejection of its Credentials, 78 AM. J. INT'L L. 179 (1984).

136. The USSR representative argued just the opposite, stating that "the establishment of any criteria whatsoever would open the way to abuses ... there would be no protection against abuses or against the interpretation of such criteria in a manner prejudicial to the Member State of the 
3. UN Legal Counsel's Opinion on the "Scope of 'Credentials' in Rule 27 of the Rules of Procedure of the General Assembly" 137

Two decades after the Secretary-General's memorandum and Resolution 396(V), the UN Legal Counsel submitted an opinion"138 (the "Opinion") on the scope of the credentials inquiry possible under Rule $27 .{ }^{139}$ Counsel began its Opinion by stating that the UN Rules of Procedure do not contain a specific definition of credentials, though Rule 27 specifies that the credentials must designate the representatives, must be submitted to the Secretary-General, and must be issued by the Head of the State or Government or by the Minister for Foreign Affairs. ${ }^{140}$ Counsel defined credentials as "the document attesting that the person or persons named are entitled to represent their State at the seat of or at meetings of the [UN]."141 Yet Counsel maintained the UN's traditional insistence that the recognition of a government and substantive issues concerning the status of governments do not generally arise in the $\mathrm{UN}$ credentials process. ${ }^{142}$

Counsel described the only exception to this rule as occurring in the following situation: rival claimants exist and there is some substantive question as to which claimant represents the "true Goverument."143 In this situation, the Opinion stated that it is permissible to consider the representation question within the context of credentials verification, or as a separate agenda item in the General Assembly. ${ }^{144}$ However, Counsel did not address whether one forum was more or less appropriate, nor did it offer guidance on how to address this substantive question. Thus, the same problems of ambiguity and ineffectiveness that arose with Resolution 396(V) continue here.

Taken together, the Secretary-General's letter proposing an effective control test, Resolution 396(V) proposing a test considering the "Purposes and Principles" of the Charter, and the Legal Counsel's Opinion on Rule 27 identifying the credentials process as an appropriate forum for

Organization to which they were being applied." U.N. Doc. A/PV.325, supra note 124, 11 149, at 676. In particular the USSR's representative argued that the United States was using the establishinent of criteria to achieve its political end of keeping communist China from representation in the UN. See id. III $146,148,154$, at $675-76$.

137. UN Legal Counsel's Opinion, supra note 77, at 3.

138. See id.

139. See id.

140. See General Assembly Rules of Procedure, supra note 57, Rule 27.

141. UN Legal Counsel's Opinion, supra note 77, at 3 n.1.

142. See id. III 3-4 ("[N]ormally the examination of credentials, both in the Credentials Committee and in the General Assembly, is a procedural matter limited to ascertaining that the requirements of rule 27 have been satisfied.").

143. Id. $\mathbb{1} 4$.

144. See id. The remainder of the Opinion was dedicated to discussing the situation where only one claimant presents credentials that meet the requirements of Rule 27. This discussion inay be a response to the Greek representative's request for the Legal Counsel's opinion on the discussion surrounding a proposal to reject South African credentials. See Jhabvala, supra note 8, at 633 n.88. 
representation disputes among rival claimants begin the difficult task of establishing an effective method for consistently dealing with representation disputes. However, the UN organs do not apply all three of these proposals to actual disputes. Thus, ambiguity exists not just within the evaluation processes offered, but also in the interaction of these processes when an actual dispute is under review. As Part IV shows through a case study of Cambodian accreditation and representation disputes, neınber states pick and choose the factors and considerations best suiting their individual political positions instead of applying a consistent standard. ${ }^{145}$

The time has come for the UN to create a clear guide for the resolution of representation disputes among rival governments. Such a guide would provide for inore consistent outcomes and would enable the UN to encourage member states to adhere to international human rights standards. The Accreditation Proposal set forth in Part III is intended as a starting point for renewed discussion of representation issues within the United Nations. Over forty years have passed since the Dominican Republican delegate noted that representation is a question of "utmost importance" which must be carefully studied. ${ }^{146}$ The need for study must now give way to a plan for definitive action.

\section{III}

The ACCREDitation Proposal:

\section{A NeW Way to Determine REPRESENTATION}

This Comment proposes that the General Assembly adopt a new set of standards for determining future representation disputes. To this end, the Accreditation Proposal explained in this Part is designed to incorporate the key eleinents of Resolution 396(V), ${ }^{147}$ the draft resolutions proposed prior to the passage of Resolution $396(V),{ }^{148}$ and the 1950 Secretary-General's Meinorandum concerning representation ${ }^{149}$ in the form of a balancing test. As discussed in Part $I$, the international community has changed significantly in the past fifty years in ways which affect representation disputes. One example of this change is the emerging prominence of universal human rights. Therefore, if the UN intends to retain its position in the international community, its process for determining representation disputes must evolve to meet those changes. After all, the representative seated in the General Assembly, and other UN organs, will influence the UN's

145. See infra Part IV. For a strong critique of member state abuse of the credentials process to punish states, see BLUM, supra note 6.

146. Report of Sub-Comm. 2, supra note $115, \$ 33$, at 11 .

147. See discussion supra Parts II.B.2.b-II.B.2.c.

148. See discussion supra Part II.B.2.a.

149. See discussion supra Part II.B.1. 
decisions on important global matters through its voting rights. ${ }^{150}$ The Credentials Committee and the General Assembly decide which régime will represent a member state where a representation dispute exists; this decision should not be taken lightly or hidden behind a procedural curtain.

The Cuban and Chinese draft resolutions that were rejected in favor of Resolution 396(V) both mvolved a balancing test in which various factors were weighed against each other. ${ }^{151}$ Resolution $396(\mathrm{~V})$, however, did not establish a balancing test. While the goal of Resolution 396(V) was to consider each representation dispute in light of the "Purposes and Principles" of the UN Charter and the circumstances of the individual case, ${ }^{152}$ it is too vague to fulfill this function. A balancing test is needed that will ensure the consideration of certain important factors in every single dispute, while allowing for circumstances umique to each dispute. The proposals that the Ad Hoc Political Committee considered prior to the General Assembly's passage of Resolution $396(\mathrm{~V})$ contain a variety of factors valuable to the determination of representation. ${ }^{153}$ The first step in formulating the proper test, however, is choosing a forum.

\section{A. Procedural Aspects of the Accreditation Proposal: Choosing a Forum}

The Legal Counsel's Opimion on Rule 27, discussed in Part II.B.3, clarifies that either the Credentials Committee or the General Assembly may consider a representation dispute. The Accreditation Proposal put forth here proceeds one step further by requiring consideration in both forums. This requirement is consistent with the existing General Assembly Rules of Procedure and with the Legal Counsel's Opinion on Rule 27.

\section{The Credentials Committee}

The Credentials Committee should be the initial forum for a representation dispute. If a representation dispute is raised first in the General Assembly, under Rule 65 of its Rules of Procedure, the General Assembly should defer its decision until the Credentials Committee has submitted its report. ${ }^{154}$ The Accreditation Proposal extends this rule slightly by providing that the General Assembly should defer any discussion of representation

150. See General Assembly Rules of Procedure, supra note 57, Rules 82-89 (describing the voting rights of General Assembly member states).

151. See discussion supra notes 99-104 and accompanymg text.

152. See General Assembly Resolution 396(V), supra note 83.

153. Of those proposals, the Cuban resolution provides the most complete foundation for a balancing test because it considers: effective control, consent of the population, ability and willingness to fulfill international and Cliarter obligations, and respect for liuman rights. See Cuban Draft Resolution, supra note 98 , T1 1 , at 5.

154. See General Assembly Rules of Procedure, supra note 57, Rule 65. For the text of Rule 65, see supra note 62 . 
disputes until the Credentials Committee has considered and discussed all elements of the required balancing test and has submitted its report recommending the acceptance or rejection of each representative's credentials. This extension is consistent with the Legal Counsel's Opinion on Rule 27, which specifically names the Credentials Committee as an appropriate forum for considering representation disputes. ${ }^{155}$

Further, the Credentials Committee logically should be involved in each representation dispute because any government proclaiming itself the rightful representative of a member state eventually must submit its credentials to the Credentials Committee pursuant to Rule 27 of the General Assembly's Rules of Procedure. ${ }^{156}$ Rule 27 requires member states to submit their delegation's credentials prior to the start of each General Assembly session. ${ }^{157}$ Though a representation dispute may arise at any time during a General Assembly session, and that dispute may be discussed in other UN organs, it is solely the province of the Credentials Committee to verify a delegation's credentials and recommend that the General Assembly accept those credentials. ${ }^{158}$

Thus, when a representation dispute exists, the Credentials Committee would substantively consider which of the rival delegations truly represents the member state. In reality, the Credentials Committee already makes this decision through the acceptance of one set of credentials over another. However, in reaching this decision under the Accreditation Proposal, the Committee would apply the four-factor balancing test discussed in Part III.B. Only after this substantive consideration would the Committee proceed with verifying that the representative's credentials meet the procedural requirements set forth in Rule 27.159 The Committee would then submit its report to the General Assembly. The report would contain the substantive discussion of the representation dispute under the balancing test, and a recommended draft resolution on whether the General Assembly should accept or reject the representative's credentials. If the Credentials Committee was unable to reach a conclusion regarding the representation dispute, it would recommend that the member state's seat remain empty during that session. After the Committee submitted its recommendation, the General Assembly would then engage in the same evaluation process.

155. See UN Legal Counsel's Opinion, supra note 77.

156. See General Assembly Rules of Procedure, supra note 57, Rule 27.

157. See id.

158. See id.

159. See supra note 64 and accompanying text (describing the procedural requirements of Rule 27). 


\section{The General Assembly}

Since the Credentials Committee consists of only nine member states each session, and therefore does not represent the UN General Assembly as a whole, the General Assembly would also consider each representation dispute after the Credentials Committee submits its report. This report, containing the Committee's evaluation of the representation dispute, provides a good starting place for the General Assembly's application of the balancing test. Under the Accreditation Proposal, the General Assembly would consider each of the four balancing test factors to determine if it agrees with the Credentials Committee's recommendation. Following its discussion, the General Assembly would vote to accept or reject the Committee's recommended draft resolution. This discussion and voting would occur within the permanent agenda item assigned to discussions of the Credentials Committee's report. ${ }^{160}$

\section{Disputes Arising Within a General Assembly Session}

Representation disputes can and do arise in the middle of a General Assembly session. In these cases, the member state already has a representative seated in the General Assembly. Under Rule 29, that representative continues to hold the member state's seat until the beginning of the following session when the Credentials Committee makes its report and the General Assembly makes its decision. ${ }^{161}$ This rule supports the "premature recognition doctrine," which prevents recognition of a new government until its control of the state is well established. ${ }^{162}$ The Accreditation Proposal would not change this procedure. Once the representatives have been chosen for a General Assembly session, those representatives should remain for the duration of the session. However, full discussion of a dispute should ensue under the guidelines of the Accreditation Proposal

160. Under Rule 12 of the Rules of Procedure, the General Assembly's agenda includes discussion of various items; some items are raised in every session, some items are continued from the previous session, and some items are proposed for the first time by a UN organ, member state, or SecretaryGeneral. See General Assembly Rules of Procedure, supra note 57, Rule 12. Each session the General Assembly discusses and votes on the Credentials Committee's report under Agenda Item 3; thus, the record of the General Assembly's decisions is accessible to interested individuals and organizations. However, representation disputes raised separately within the General Assembly currently are discussed under agenda items whose number varies among the disputes. By deferring all Gencral Assembly diseussion until the Credentials Committee has submitted its report, the discussions would be consolidated under Agenda Item 3. This consolidation would provide one method of accountability to ensure member states are consistently applying the required balancing test by making the discussions more accessible to the publie and other international organizations.

161. See General Assembly Rules of Procedure, supra note 57, Rule 29 ("Any represcntative to whose admission a Member has made objection shall be seated provisionally with the same rights as other representatives until the Credentials Committee has reported and the General Assembly has given its decision.").

162. See H. LAUTERPacht, ReCOGNITION IN INTERNATIONAL LAW 94-96 (AMS Prcss 1978) (1948). 
before that member state's representative is chosen for the subsequent session.

This full discussion of the dispute before the next session potentially conflicts with the premature recognition doctrine. In the context of General Assembly sessions, the premature recogmition doctrine would presume that the previous session's representative should remain the representative unless and until the challenging régime can prove that it has effective control of the state. ${ }^{163}$ While this doctrine is partially incorporated under the first factor of the balancing test in the Accreditation Proposal, ${ }^{164}$ the doctrine would not operate to the exclusion of other considerations. Further, contrary to the premature recognition doctrine, the Accreditation Proposal would support the possibility of leaving the member state's seat in the General Assembly empty. ${ }^{165}$

Finally, the General Assembly's decision in a representation dispute would be binding on all UN organs subsidiary to the General Assembly. This provision differs from Resolution 396(V) which only makes the General Assembly's decision persuasive. ${ }^{166}$ Granting the General Assembly binding authority is necessary to avoid the concern which originally inspired the entire debate leading up to Resolution 396(V), namely the fear that separate UN organs would reach different decisions on representation, causing confusion and contradiction within the institution. ${ }^{167}$ Under the Accreditation Proposal, this risk of internal inconsistency is eliminated.

The purpose of involving both the Credentials Committee and the General Assembly in resolving representation disputes is to achieve the fullest possible discussion before 1naking a choice between régimes within a member state. Despite the infrequency of major representation disputes, ${ }_{168}{ }^{16}$ the decision is important, both for the UN and for the regime recognized as the UN representative. There is thus a pressing need for a mechanisnı which will lead to coinprehensive and consistent resolution of representation disputes.

\section{B. Substantive Aspects of the Accreditation Proposal: A Balancing Test}

The Accreditation Proposal requires the application of a four-factor balancing test to every representation dispute. Both the Credentials Committee and the General Assembly would base their consideration of a dispute on the following criteria: 1) whether a régime maintams effective

163. See id.

164. See infra Part III.B.1.

165. This was the result reached by the General Assembly in the 1997 Cambodian representation dispute. See U.N. GAOR 52d Sess., Agenda Item 3, II 5, U.N. Doc A/52/719 (1997).

166. See General Assembly Resolution 396(V), supra note 83.

167. See discussion supra Part II.B.

168. The only major credentials disputes have involved China, Hungary, the Congo, Yemen, Israel, South Africa, and Cambodia. See BLUM, supra note 6, at 33-56; RoTH, supra note 6, at 411-57. 
control over the national territory and population of the member state; 2) whether a régime maintains its power with the general consent of the population; 3) whether a régime is willing and able to achieve the purposes of the UN Charter, to observe its principles, and to fulfill international obligations of the member state; and 4) whether a régime respects the human rights of the member state's inhabitants.

Evaluation of a representation dispute would begin with the first factor, effective control. Following application of the effective control test, the subsequent three factors could be considered in any order, as each of the remaining factors is equally important. Though effective control is measured first, any of the latter three factors imight swing the balance definitively based on the circumstances of the dispute. These factors represent the spectrum of criteria raised prior to the adoption of Resolution $396(\mathrm{~V}),{ }^{169}$ and take into account the practical question of which government actually controls the state as well as the question of which government truly represents the people of the state. Clearly, these factors, to a varying degree, require subjective evaluation of the dispute. Such subjective evaluation opens the door to some level of political manipulation. However, the factors provide a concrete framework for this evaluation, and would significantly decrease the likelihood of political manipulation where the evidence presented clearly weighs in favor of or against a particular régime in the representation dispute.

\section{Effective Control}

The balancing test's first factor combines the effective control test with a modified version of the premature recognition doctrine. Under the Accreditation Proposal, the Credentials Committee and the General Assembly would consider this factor before addressing the other three factors because this factor deals with the practical reality of actual, or de facto, control. In applying this factor to a representation dispute, the Credentials Committee and General Assembly would attempt to determine whether one régime "exercises effective control and authority over all or nearly all the national territory, and has the obedience of the bulk of the population of that territory, in such a way that this control, authority and obedience appear to be of a permanent character." 170

If one régime clearly maimtains this level of control in a member state, then the Credentials Committee and the General Assembly would presume that the régime is the member state's representative. This presumption of recognition only applies to disputes where one régime maintains extensive physical control of a member state. The requirement that the régime's authority "appear to be of a permanent character" protects against

169. See discussion supra Part II.B.

170. U.K. Draft Resolution, supra note $98, \mathbb{1} 1$, at 6. 
recognition based on vacillating power over short-term periods. This factor resembles the premature recognition doctrine because it denies presunied recognition to a challenging régime until that régime clearly establishes its de facto control over time. However, the factor differs from the doctrine by not automatically creating a presumption in favor of the challenged government; the challenged government must clearly maintain effective control as defined above before a presumption of recognition applies. This presumption is not absolute. The other three factors in the balancimg test can override the presumption if they weigh heavily against the réginie demonstrating effective control.

In many disputes, no régime maintains this clear level of effective control. In these cases where rival régimes each control sonie part of the member state's territory and population, but no régime controls a significant majority, the presumption of recognition would not apply. Rather, this factor would be equally weighted against the other three factors. If the Credentials Committee and the General Assenibly determine that one régime maintains more control than another, although not to the level of effective control, then the factor would weigh in favor of the régime exercising the niost control. Analysis of the other three factors would then proceed.

\section{Willing Consent of the Population}

One of the three other factors the Credentials Committee and the General Assembly would consider is whether a régime rules with the willing consent of the population. This factor is closely tied to the effective control factor since the issue of willing consent is moot if a régime has never commanded actual control within a member state. The most obvious method of gauging the willing consent of a population is through an election process. As provided in Article 21 of the Umiversal Declaration of Huinan Rights, "[e]veryone has the right to take part in the government of his country ... [and] [t] he will of the people shall be the basis of the authority of government; this will shall be expressed in periodic and genuine elections ...."171 Though this provision raises definition problems regarding what constitutes "periodic and genuine elections," it provides a good starting point for discussing whether a government has the popular support of its people.

This factor weighs in favor of a popularly elected government and weighs against a régime which takes power through military or political force without being elected. The latter category might also include incidents of foreign intervention, where a particular régime achieves power through the external assistance of another state. The modern international

171. Universal Declaration of Human Rights, supra note 19, at 75 . 
community has cultivated a strong dislike for the interference of foreign nations into another state's domestic conflicts, especially in situations where a strong nation props up its favored government in a weaker nation. Such governments are referred to as "puppet régimes" 172 and the UN generally does not view them as true representatives of a member state. ${ }^{173}$ Thus, even when a government has obtained a presumption of recognition under the effective control factor, the presumption is eliminated if it came to power largely through foreign assistance or interference. ${ }^{174}$

Keeping in mind the reality that member states operate under a wide variety of political systems, some of which may not include electoral processes and democratic governance, the willing consent factor would allow the Credentials Committee and the General Assembly to gauge the degree of the population's willing consent through other, non-electoral means. The particular circumstances of each dispute would dictate what other gauges of support would be appropriate; however, negative indicators might include the level of public opposition to the government, measured through rallies, speeches, polls, literature, and the media, or even the government's suppression of such public opposition. Consideration of such indicators might overlap with evaluation of the human rights factor, discussed in Part III.B.4. Such overlap is natural within the latter three factors since they measure the degree to which a government truly represents the member state's population.

\section{Willingness to Meet UN and Other International Obligations}

Another factor the Credentials Committee and the General Assembly would consider in evaluating a representation dispute is whether each rival régime is willing and able to achieve the purposes of the UN Charter, to observe its principles, and to fulfill international obligations of the member state. This factor is tied to the effective control test in the sense that a régine which does not wield actual physical control in a member state, may not be able to fulfill the member state's UN and international obligations, regardless of how willing it is. This factor is also closely related to the other two factors of willing consent and human rights because all of these factors are embodied within the purposes of the UN Charter. The

172. See, e.g., U.N. GAOR, 324th Sess., Annexes, Agenda Item 3, I 9, at 2, U.N. Doc. A/34/500 (1979) (referring to the "puppet régime of the Vietnamese authorities [that] had been repudiated by the Cambodian people and represented no one").

173. The General Assembly, however, did recognize the Lon Nol government in Cambodia from 1970 to 1975, despite accusations and evidence that the régime received extensive support from the United States. See discussion infra Parts IV.A.2-IV.A.3.

174. The fact that a régime initially achieved its power through foreign assistance or intervention would not negate the possibility that the régime may later retain its power with the willing consent of the population. Depending on the circumstances of the particular dispute, this faetor may weigh in favor of a régime that originally came to power under foreign assistance, but which gaincd and maintained the willing consent of the population prior to UN evaluation of the representation dispute. 
concept of willing consent is incorporated under the UN's purpose in Article 1, Paragraph 2 of "develop[ing] friendly relations among nations based on respect for the principle of equal rights and self-determination of peoples. ..." "175

The next purpose, espoused in Article 1, Paragraph 3, is "[t]o achieve international cooperation ... in promoting and encouraging respect for human rights and for fundamental freedoms for all without distinction as to race, sex, language, or religion." 176 Article 55 also specifies that in order to achieve the stability necessary for friendly relations among nations based on equal rights and self-determination, the UN shall promote, among other things, universal respect for, and observance of, hunian rights and fundamental freedoms. ${ }^{177}$ Member states are pledged to take joint and separate action to achieve the purposes of Article $55 .{ }^{178}$ Despite these references in the UN Charter, the issues of willing consent and human rights remain separate factors to ensure that the Credentials Committee and the General Assembly consider each one in full and apart from the remaining Charter principles and obligations.

A member state maintains numerous other obligations under the $\mathrm{UN}$ Charter that would be considered within this factor. Under Article 2, member states are required to "fulfil in good faith the obligations assumed by thein in accordance with the present Charter."179 Meinber states are obliged to settle their international disputes by peaceful means so as not to endanger international peace and security, ${ }^{180}$ must give the UN assistance in every action it takes, and are prohibited from assisting states agamst which the UN is taking action, ${ }^{181}$ must pay their dues to support the UN financially; ${ }^{182}$ must accept and carry out Security Council decisions under the Charter; ${ }^{183}$ must undertake to comply with. International Court of Justice decisions involving them; ${ }^{184}$ and must grant the UN and its representatives the legal capacity and privileges and immunities necessary for the exercise of UN functions and the fulfillment of UN purposes. ${ }^{185}$

This factor would require not only consideration of whether a régime is both willing and able to meet all of these UN obligations, but also

175. U.N. CHARTER art. 1, para. 2.

176. Id. art. 1, para. 3.

177. See id. art. 55 .

178. See id. art. 56.

179. Id. art. 2, para. 2 .

180. See id. art. 2, para. 4.

181. See id. art. 2, para. 5 .

182. See id. art. 17, para. 2 .

183. See id. art. 25. Such decisions may require member states to provide assistance including: internuption of economic relations, means of communication, and diplomatic relations under Article 41; armed forces, facilities, and rights of passage under Article 43; and air force contingents under Article 45.

184. See id. art. 94, para. 1.

185. See id. arts. 104, 105, paras. 1-2. 
consideration of whether the régime is willing and able to meet its other obligations under international agreements, either bilateral or multilateral, which the member state had undertaken. Though a régime exercising effective control over the state, especially the political and legal systems of the state, would be better able to meet all these obligations, that régime may be unwilling to do so. Thus, this factor potentially could weigh against each régime involved in a representation dispute if each régime is either unable or unwilling to ineet the meinber state's UN and international obligations. It may not be ascertainable whether any of the régimes is either willing or able to meet these obligations; in these cases, the factor would not weigh for or against the régimes.

A régime that is unable or unwilling to ineet the member state's obhgations might still be the true representative of the people, in terms of the population's willing consent; however, the régime may not qualify as a member state's representative for UN purposes. The UN Charter obligations listed above are requirements, on which a member state's voting privileges and very membership in the UN are hinged. The member state's rights and privileges may be suspended, ${ }^{186}$ or the member state may be expelled upon the recommendation of the Security Council $1 .^{187}$ Thus, inclusion of this factor is appropriate in determining which régime should represent a inember state in the UN General Assembly.

\section{Respect for Human Rights and Fundamental Freedoms}

Under the Accreditation Proposal, every representation dispute would include inandatory consideration of whether each rival régime has respected the huinan rights of the inember state's inhabitants. As discussed extensively in Part I of this Comment, human rights law has become a significant facet of the international community over the past fifty years, and the UN lias played an important role in its development. The UN has pledged itself and its inember states to promoting universal respect for fundamental human rights and the dignity and worth of the human person, ${ }^{188}$ accordingly, the UN nuust now turn a spotlight into the very depths of its own imstitutional structure to proinote the human rights of every person. Consideration of human rights within the UN accreditation process would inove the UN one step closer to fulfilling this purpose.

Evaluation of each régime's human rights record would be based on the framework provided in the Universal Declaration of Human Rights, which the General Assembly adopted in $1948 .{ }^{189}$ The Universal Declaration is viewed as "one of the fundamental parameters with which the

186. See id. arts. 5, 19.

187. See id. art. 6 .

188. See U.N. Charter preamble.

189. See Universal Declaration of Human Rights, supra note 19. 
international commumity delegitimizes states. A state that systematically tramples the Declaratiou under foot is not regarded as worthy of approval by the world community." 190 Nor should such a state be worthy of approval within the UN itself. The Universal Declaration provides a groundwork for consideration of human rights that has been long established within the international community and long accepted by the General Assembly. In addition to the Universal Declaration, this factor would eniphasize consideration of the core human rights which have achieved status as customary international law binding on all states, namely prohibitions agamst genocide, torture, and slavery. ${ }^{191}$

The Universal Declaration contains thirty articles setting forth the universal rights of every human person. These rights include: the right to life, liberty, and security of one's person; ${ }^{192}$ the right to equality as a person before the law, and equal protection of the law, ${ }^{193}$ the right to effective remedy before a competent court, a fair and public hearing, and a presumption of innocence; ${ }^{194}$ the right to privacy and freedom of movement; ${ }^{195}$ the right to nuarriage without discriminatory limitations and to own property:196 the right to freedom of thought and expression, to peaceful assembly, and participation in the government of one's state; ${ }^{197}$ and the right to education and participation in the cultural life of the state. ${ }^{198}$

In addition, the Universal Declaration parallels international customary law in prohibiting slavery, ${ }^{199}$ and torture, ${ }^{200}$ and also prohibits cruel, inhunian, or degrading treatment or punishment, ${ }^{201}$ and arbitrary arrest, detention, or exile. ${ }^{202}$ The violation of these additional prohibitions would weigh most heavily agamst a régime, as would the commission of genocide or mass extermination of human beings. ${ }^{203}$

The Credentials Committee and the General Assembly would evaluate each régime under this factor, which would weigh im favor of a régime that

190. CASSESE, supra note 17, at 46-47. For an excellent discussion of the context leading up to and including the adoption of the Universal Declaration, as well as its significance in the modern international community, see $i d$. at 28-47.

191. See discussion supra Part I.A.

192. See Universal Declaration of Human Rights, supra note 19, art. 3.

193. See id. arts. 6-7.

194. See id. arts. 8, 10-11.

195. See id. arts. 12-13.

196. See id. arts. 16-17.

197. See id. arts. 18-21.

198. See id. arts. 26-27.

199. See id. art. 4.

200. See id. art. 5.

201. See id.

202. See id. art. 9.

203. Mandatory consideration of this factor would have prevented the Khmer Rouge's Democratic Kampuchea government from being accredited as Cambodia's representative, as the government's massive violations of hunian rights would have tipped the balance decisively agamst it. See discussion infra Part IV.B. 
respects the human rights of the member state's inhabitants, and would weigh against a régime that violates those human rights. If every régime mvolved in a representation dispute is guilty of human rights violations, the factor would weigh against each régime to the degree of its violations. These human rights also are somewhat hierarchical; thus, the factor would weigh more heavily against a régime violating the prohibitions against genocide, unlawful killing, torture, inhumane treatment, slavery, and arbitrary detention than it would against a régime violatimg the right to participate $\mathrm{m}$ the cultural life of a member state.

\section{The Accreditation Proposal: A Better Solution}

The Accreditation Proposal cannot guarantee total deterrence of political manipulations within the accreditation process. I assert that no proposal could completely ensure that UN member states would not succeed in using the process to achieve their own political interests. However, the Accreditation Proposal's balancing test forces member states to address each of the four factors, and to couch their arguments in terms of these factors. The procedural structure of the Accreditation Proposal creates a mechanism of accountability by streamlining all discussion of representation disputes under one agenda item that is accessible to the public and to other governmental and non-governmental organizations. It then falls to individuals and other organizations to hold their own member state accountable for the consistency of that state's discussion and voting practices in representation disputes.

Part IV of this Comment undertakes analysis of the three Cambodian representation disputes that have arisen since 1970. The analysis of how the UN resolved those disputes, taken individually and together, highlights the shortcomings of the current accreditation process discussed in Part II. Retrospective application of the Accreditation Proposal's balancing test to each Caunbodian dispute illustrates the positive effects that a consistent accreditation process can have on representation disputes over time.

TV

\section{Case Study: Cambodia's Representation Disputes BETWEEN 1970 AND 1997}

Canıbodia has struggled with both ongoing internal conflict and repetitive foreign intervention almost continuously since the end of World War II. ${ }^{204}$ Caunbodia achieved independence from France in 1953. Its ruler at the time, Prince Norodom Sihanouk, sought to maintain Cambodia's independence through a policy of neutrality toward other countries. ${ }^{205}$ This

204. See Steven R. Ratner, The Cambodia Settlement Agreements, 87 AM. J. INT'L L. 1 (1993).

205. See Stephen J. Solarz, Cambodia and the International Community, in Honoring Human Rights and Keeping the Peace 101 (Alice H. Henkin ed., 1995). 
attempt at autonomy met with some success until the Vietnam Conflict turned Southeast Asia into a strategic battlefield. As Vietnam's immediate neighbor, Cambodia could not escape becoming a pawn manipulated by both sides of the Conflict. Sihanouk's decisions during the Conflict, together with the rise of a rogue group of communists, later known as the Khmer Rouge, led to the chain of events creating civil unrest and bloodshed in Cambodia for the next three decades. ${ }^{206}$ During this period, Cambodia experienced three representation disputes over its seat in the UN General Assembly. Examination of how these disputes ultimately were resolved illustrates the need for the Accreditation Proposal.

\section{A. 1973 Dispute}

\section{Historical Background}

From the time of Cambodian independence in 1953 until the late 1960 s, Sihanouk remained ruler through overwhelming popular support. In the 1955 elections, his party won eighty-three percent of the vote and all the seats in the National Assembly. ${ }^{207}$ This personal popularity alone could not maintain Sihanouk's support as the Vietnam Conflict dragged on, however. Sihanouk's repeated atteinpts at neutrality during this period upset both anti-Communist and pro-Communist Cambodians. Forced into action by the superpowers involved in the Conflict, Sihanouk tried to appease both sides, resulting in decisions which seemed to contradict each other. He looked the other way when North Vietnamese Viet Cong used Cambodian sections of the Ho Chi Minh Trail to rest its troops and transport supplies to South Vietnam. ${ }^{208}$ Then, in 1967 and 1968, he indicated that he would permit South Vietnamese or U.S. troops to pursue Viet Cong into Cambodia and attack North Vietnamese stations in Cambodia. ${ }^{209}$ The United States, a long time supplier of military aid to Canıbodia, was allowed to operate bombing canxpaigns in the Cambodian countryside to obhiterate Viet Cong strongholds. ${ }^{210}$

At the sane time that Sihanouk was restoring diplomatic relations with the United States, he also was making Cambodia the first foreign government to recognize North Vietnam's provisional government in South Vietnam, the National Liberation Front of South Vietnam

206. See id; see also Cambodia Rivals Lobby UN (National Public Radio, Morning Edition, Oct. 1, 1997), available in 1997 WESTLAW 12823385.

207. See Seekins, supra note 2, at 29.

208. See Nhan T. Vu, The Nondemocratic Benefits of Elections-The Case of Cambodia, 28 CASE W. Res. J. INT'L L. 395, 406 (1996) (citing Donald M. Seekins, Historical Setting, in Cambodia: A Country Study 31-32 (Russell R. Ross ed., 3d ed. 1990)).

209. See Seekins, supra note 2, at 34 .

210. See Solarz, supra note 205, at 101. For a discussion of the volatile nature of Sihanouk's relationship with the United States, see Seekins, supra note 2, at 32-35. 
(NLFSVN). ${ }^{211}$ Adding to growing dissatisfaction with Sihanouk within his own party were tensions within Cambodia's communist factions. The Cambodian Communist Party, backed by Vietnam and China, was being challenged by the Khmer Rouge, which resented Vietnamese interference in the party. ${ }^{212}$

Besieged by difficulties on all sides, Sihanouk's power began to crumble. On March 18, 1970, while Sihanouk was on a diploniatic mission to Moscow and Beijing, his Prine Minister, General Lon Nol, usurped Sihanouk's position in a coup d'état. ${ }^{213}$ The Cambodian National Assen1bly, controlled by Lon Nol supporters, voted unanimously to endorse the coup d'état and depose Sihanouk. ${ }^{214}$ Several commentators have directly linked the United States to Lon Nol's coup, with one even charging that "[t]he United States deposed Sihanouk in 1970 in favor of a régime which would allow the United States to fight the Vietnam War on Cambodian soil." "215 Sihanouk quickly established a governınent-in-exile, called the Royal Government of National Union of Cambodia (GRUNK), in Beijing. The UN Credentials Committee, however, accepted the credentials of Lon Nol's new government, the Khmer Republic, without objection. In 1970, the UN seated a delegation of the Khmer Republic in the UN General Assenibly. ${ }^{216}$ Lon Nol quickly and openly collaborated with the United States in moves against North Vietnamese sanctuaries in Cambodia. ${ }^{217}$

\section{The Dispute}

Knowing that his power alone was insufficient to challenge Lon Nol, Sihanouk allied GRUNK with the Khmer Rouge guerrilla forces. By 1973, this alliance regamed enough control of Canıbodian territory and support within the international community to challenge the accreditation of Lon Nol's government for the twenty-eighth session of the UN General Assembly. GRUNK arranged for its supporters to send a letter to the Secretary-General requesting that the issue of "[r]estoration of the lawful

211. See Seekins, supra note 2, at 34-35. Cambodia's ties with the United States had been severed in 1965 , after almost a decade of economic and military support totaling about $\$ 400$ million. See id. at 33-34.

212. See id.

213. See Marc B. Dorfinan et al., Note, The United Nations, 28th Session: Cambodian Representation, 15 HARV. INT'L L.J. 495, 496 (1974) [hereinafter Cambodian Representation].

214. See Seekins, supra note 2 , at 43.

215. Note, The War in Cambodia and the Case for Judicial Enforcement of Human Rights Conditions on Foreign Aid, 30 Colum. J. of TransNaT'L L. 661, 665 (1992) [hereinafter The War In Cambodia].

216. See G.A. Res. 2636 (XXV), U.N. GAOR, 25th Sess., Supp. 28, at 6, U.N. Doc. A/8028 (1970).

217. See KLINTWORTH, supra note 3, at 4. This military action ineluded an extremely heavy campaign of American B-52 bonbings in the Cambodian countryside, which contributed to anti-Lon Nol sentiment. See id; see also William Shawcross, Sideshow: Kissinger, Nixon and The Destruction of CAMBodia (1987) (describing the U.S. bombing campaigns in Cambodia). 
rights of the Royal Government of National Union of Cambodia in the United Nations" be added as a separate item in the General Assembly's agenda. ${ }^{218}$ Attached to the letter was a draft resolution which, if adopted, would have restored GRUNK as Cambodia's representative in the General Assembly. ${ }^{219}$ Sihanouk strategically raised the issue directly before the General Assembly, rather than through the Credentials Committee, where Lon Nol's American ties would work strongly agamst GRUNK's success.

The General Committee of the General Assembly recommended that the General Assembly include GRUNK's restoration as Cambodia's UN representative on the agenda as a separate item from the Credentials Committee's regular report. ${ }^{220}$ Discussion within the General Assembly ensued. Resolution 396(V), the guide for representation disputes in 1973, as it is today, calls for consideration of the situation in light of the "Purposes and Principles" of the UN Charter. Due to the vague nature of this guideline, however, almost the entire General Assembly debate was couched in terms of effective control, a consideration that is not mentioned im Resolution 396(V). A few delegates based their arguments on the various principles and purposes stated in the Charter, but the recurring question throughout was which of the two governments exercised actual control of the population and the territory of Cambodia.

Both GRUNK and the Khmer Republic proclaimed themselves the legitimate government of Cambodia with effective control of the state. Sihanouk claimed that GRUNK was a functioning government within Cambodia based on its control of eighty percent of Cambodia's territory and ninety percent of the country's population, though the Khmer Republic held Phnom Penh and several other major cities. 221 The Khmer Republic claimed to control six-sevenths of the population and "most" of the territory, while acknowledging its lack of control in four northeastern provinces. ${ }^{222}$ The UN delegate of the Khmer Republic argued that GRUNK could not be considered an effective government. He asserted that GRUNK did not govern from within Cambodia, that it lacked control over the Khmer Rouge forces it claimed alliance with, and that any minimal control depended on foreign troops. ${ }^{223}$ The General Assembly could not answer the effective control question while the power struggle within Cambodia remained unresolved. The facts demonstrated that both governments

218. U.N. GAOR, 28th Sess., Annexes, Agenda Item 106, at 1, U.N. Doc. A/9195 (1973). Thirtytwo member states signed the letter.

219. See U.N. GAOR, 28th Sess., Annexes, Agenda Item 106, at 2, U.N. Doc. A/L.714 (1973).

220. See U.N. GAOR, 28th Sess., Annexes, Agenda Item 8, at 21, U.N. Doc. A/9200/ADD.4

(1973). Recommendation was made by a vote of eleven to two, with ten abstentions.

221. See Cambodian Representation, supra note 213, at 497.

222. See id.

223. See U.N. GAOR, 28th Sess., 2188th plen. mtg., Agenda Item 8, TII 27, 32, at 4, U.N. Doc. A/PV.2155 (1973). 
maintained sigmificant control within different regions of Cambodia, and that even that control shifted on a regular basis. ${ }^{224}$ Abandoning the effective control test as ambiguous, the debate turned to other issues.

Supporters of GRUNK focused on the foreign support Lon Nol received from the United States, relying on the UN position against foreign intervention in internal power struggles, as embodied in Article 2, Paragraph 7 of the Charter. ${ }^{225}$ The argument asserted that the United States and "people in its pay"226 instigated and supported Lon Nol's coup d'état. Other GRUNK supporters raised a self-determination argument based on Article 1 of the Charter. ${ }^{227}$ That argument maintained that denial of GRUNK representation equaled a denial of Cambodians' right to be truly represented in the United Nations. ${ }^{228}$

UN member states supporting Lon Nol relied on the principle of domestic non-interference found in Article 2 of the Charter. ${ }^{229}$ In a letter submitted to the General Assembly, they asserted that the question of Cambodia's legitimate government was a political question for the people of Cambodia, not for the UN General Assembly. ${ }^{230}$ At the same time, the Lon Nol government claimed that Sihanouk himself was guilty of high treason for calling forth rebellion within Cambodia. ${ }^{231}$

By a close vote of fifty-three in favor and fifty opposed, the General Assembly postponed any decision on the issue of Cambodian representation until the following session. ${ }^{232}$ Later in the same session, however, the issue arose again when Senegal's representative submitted a report to the

224. The facts seemed to indicate that both governments controlled some territory, but the extent of that control was hotly contested. See RoTH, supra note 6, at 445-49.

225. See U.N. ChARTER art. 2, para. 7.

226. U.N. GAOR, 28th Sess., 2188th plen. mtg., Agenda Item 6, II 5, at 1, U.N. Doc. A/PV.2188 (1973).

227. See U.N. GAOR, 28th Sess., 2189th plen. mtg., Agenda Itcm 106, II 12, at 2, U.N. Doc. A/PV.2189 (1973). Albania's rcpresentative argued that "[ $t]$ he seat of Cambodia in this Organization has been usurped by a group of individuals who do not represent, in any way, the intercsts of the Cambodian people ... [s] uch a situation constitutes a flagrant violation of the Charter ...." Id.; see also U.N. GAOR, 28th Sess., 2190th plen. mtg., Agenda Itcm 106, II 2, at 1, II 19, at 2-3, U.N. Doc. A/PV.2190 (1973). Article 1 of the Charter includes as the purposes of the UN " $[t]$ o develop friendly relations among nations based on respect for the principle of cqual rights and self-determination of peoples...." U.N. ChaRTER art. 1, para. 2 (emphasis added).

228. See U.N. GAOR, 28th Sess., 2189th plen. mtg., Agenda Item 106, II 12, at 2, II 22, at 3, U.N. Doc. A/PV.2189 (1973).

229. See U.N. GAOR, 28th Sess., 2189th plen. mtg., Agenda Item 106, II 48, at 6, U.N. Doc. A/PV.2189 (1973). Thailand's representative asserted, "It is also clear that any intervention by the United Nations in the domestic affairs of a Member State would be in contravention of Article 2, paragraph 7, of the Charter... . My delegation cannot, thcrefore, cnvisage our Organization taking any steps not in consonance with the sacred principles of non-intervention. ..." Id. III 48, 52, at 6; see also id. $\mathbb{1} 80$, at $9, \mathbb{1} 84$, at $10, \mathbb{1} 94$, at 11 .

230. See U.N. GAOR, 28th Sess., Annexes, Agenda Item 106, at 3, U.N. Doc. A/9254 (1973).

231. See U.N. Doc. A.PV.2188, supra note 226, I 81, at 8.

232. See U.N. GAOR, 28th Sess., 2191 st plen. mtg., Agenda Item 106, II 181, at 19, U.N. Doc. A/PV.2191 (1973). 
Credentials Committee calling for the rejection of the credentials of the Khmer Republic. ${ }^{233}$ The Committee rejected that proposal, ${ }^{234}$ but in its report to the General Assembly the Credentials Committee included an ainendinent proposing that the General Assembly award GRUNK Cambodia's UN seat. ${ }^{235}$ After lengthy discussion, the debate on the representation dispute was closed. Upon a vote, the General Assembly rejected the amendment. ${ }^{236}$

The General Assembly then effectively chose the Khmer Republic by default to represent Cambodia in the UN. Although the majority of the Credentials Committee plainly rejected the credentials of GRUNK in its report to the General Asseinbly, it did not expressly reject the credentials of the Khmer Republic. Thus, when the report was approved by the General Assembly in 1973, ${ }^{237}$ the Khmer Republic simply continued sending its delegation to represent Cambodia, as it had done for the previous three sessions. This result was affirmed in 1974, when the General Assembly again approved the Credentials Committee report, leaving the Khiner Republic as Cambodia's representative. ${ }^{238}$ In this inanner, the Khmer Republic retained the Cambodian seat until the Cambodian capital, Phnoin Penh, fell to Khmer Rouge forces in 1975.

\section{Analysis}

The outcoine of the 1973 representation dispute resulted largely from its movement between the General Assembly and the Credentials Committee. Under the Accreditation Proposal, discussion and resolution of the dispute would have followed the fixed pattern discussed in Part III.A. When the dispute intially was raised in the General Assembly at the start of its twenty-eighth session, the General Assembly would have deferred discussion of the dispute until it received the Credentials Committee's report, instead of beginning a discussion and then postponing it until the following session as the Assembly did in the 1973 dispute. Thus, the

233. See U.N. GAOR, 28th Sess., Annexes, Agenda Item 3, at 2, U.N. Doc. A/9179/ADD.1 (1973).

234. See U.N. GAOR, 28th Sess., Annexes, Agenda Item 3, II 12, at 2, U.N. Doc. A/9179/ADD.1 (1973).

235. See U.N. GAOR, 28th Sess., Annexes, Agenda Item 3, at 5, U.N. Doc. A.719 (1973).

236. See U.N. GAOR, 28th Sess., 2204th plen. mtg., Agenda Item 106, Il 166, at 16, U.N. Doc. A/PV.2204 (1973). The amendment was rejected by a vote of 55 in favor of rejection, 50 opposed, with 17 abstentions. Id.

237. See G.A. Res. 3181 (XXVIII), U.N. GAOR, 28th Sess., Supp. No. 30, at 8, U.N. Doc. A/9030 (1973). Several member states noted reservations that their vote in favor of Resolution 3181 (XXVII) did not indicate their acceptance of the Khmer Republic; however, these reservations did not change the Resolution's practical effect, namely approving the Khmer Republic's credentials. See U.N. GAOR, 28th Sess., 2204th plen. mtg., Agenda Item 106, II 183, at 17, II 189, at 18, II 193, at 18, U.N. Doc. A/PV.2204 (1973).

238. See G.A. Res. 3238 (XXIX), U.N. GAOR, 29th Sess., Supp. No. 31, at 5, U.N. Doc. A/9631 (1974). 
General Assembly would have instigated the Credentials Committee's discussion, rather than requiring another member state, in this case Senegal, to raise the issue in the Credentials Committee. The Credentials Committee seemed to adhere to the premature recognition doctrine in rejecting the GRUNK credentials since the Khmer Republic had retained Cambodia's seat for three sessions and GRUNK had not taken clear control of Cambodia, which would be required under the premature recognition doctrine to upset.the status quo.

Under the Accreditation Proposal, the Credentials Committee would have initiated a full discussion of the representation dispute using the fourfactor balancing test, instead of resting its decision solely on the premature recognition doctrine. The Committee first would have considered the effective control factor, and its discussion might have been very similar to the discussion initially undertaken in the General Assembly. Since neither régine inaintained clear effective control, appearing to be of a permanent nature, neither régime would have received a presunption of representation. Despite the lack of a presumption, this factor could still weigh in favor or against either GRUNK or Lon Nol's Khmer Republic under the Accreditation Proposal. Evidence that the United States substantially assisted Lon Nol in gaining and maintaining control over areas of Cambodia would weigh agaimst his réginie in the balancing test. This negative weight to the Khmer Republic also could be viewed as a positive weight for GRUNK, although GRUNK did not inamtain effective control sufficient to gain a presumption.

Next, the Credentials Committee would have considered the three reinaining factors of the Accreditation Proposal's balancing test. Determining which régime governed with the willing consent of the population would be difficult in the 1973 dispute. Sihanouk, GRUNK's leader, had inaintained the willing consent of the population through popular elections for a number of years before being ousted by Lon $\mathrm{Nol}$ in 1970. However, when Lon Nol took power, he did so through a legislative vote, which inay be considered the willing consent of the population through their legislative representatives. Adding to the complexity is the United States assistance to Lon Nol, which would tend to negate his claim to willing consent of the population. The consistent support GRUNK received in the General Assembly, evidenced by the pattern of voting in the 1973 dispute, likely was based at least in part on the fact that "for much of the world, the GRUNK represented the cause of national self-determination in the struggle against the neo-colonialism thought to be embodied in U.S. policy throughout Indochina."239 Thus, the willing consent factor very possibly could have weighed in favor of GRUNK under the Accreditation Proposal, but it would not weigh heavily against the Khmer Republic unless there

239. RotH, supra note 6, at 447. 
was strong evidence of substantial support from the U.S. or from some other foreign power.

The next factor, willingness and ability to fulfill Cambodia's UN and international obligations, almost certainly would weigh in favor of the Khmer Republic under the Accreditation Proposal. The Khmer Republic controlled Cambodia's capital, its legislature, and its major cities; thus, it largely controlled Cambodia's ability to meet UN and international obligations. Further, the Khmer Republic appeared willing to meet those obligations if it was accepted as Cambodia's representative. Under the final factor, respect for human rights, there is no indication in the 1973 dispute that either régime was gnilty of major or massive human rights violations. Thus, this factor would not weigh for or against either régime in the overall balance.

Analysis under the Accreditation Proposal's balancing test tends to favor GRUNK very slightly over the Khmer Republic, but does not overwhelmingly favor either régime. Therefore, it is possible that the Accreditation Proposal would lead to an outcome opposite to that actually reached in the 1973 dispute where the Khmer Republic was recognized as Cambodia's representative. Regardless of which régime the Credentials Committee ultimately chose as the appropriate representative, it would then proceed with procedural verification of the credentials under the requirements of Rule 27. Following positive verification, the Committee would submit its report to the General Assembly, clearly indicating which régime, if any, it recommended for acceptance as Caunbodia's representative, and clearly indicating its rejection of the other régimes, supplemented by a summary of the discussion supporting this recommendation. Then, under the Accreditation Proposal, the General Assembly would begin its first discussion of the representation dispute.

The General Assembly would apply the same four-factor balancing test as discussed above before voting whether to approve the Credential Committee's report. This process would have avoided the maneuverings that occurred in the actual 1973 dispute, where the Credentials Committee subimitted its report to the General Assembly and the Assembly voted without ever resuming its postponed discussion of the dispute, thereby effectively hiding behind the procedural credentials process and avoiding the complicated issues of the debate. The Accreditation Proposal is designed to block such a maneuver and to force the General Assembly to deal fully with each representation dispute no matter how complicated the issues. The General Assembly's intial discussion of the 1973 dispute further illustrates the inadequacy of the current guidelines under Resolution 396(V), since effective control, an important indicator of representativeness and the unajor focus of the General Assembly's discussion, is not included in Resolution 396(V). 
Even with application of the Accreditation Proposal's balancing test, the 1973 dispute would be a close call; however, this application would succeed in providing a consistency to the process which would benefit future disputes. In this case, the General Assembly chose to continue recognizing Lon Nol's Khmer Republic as Cambodia's representative; however, even the UN's acceptance of the status quo in Cambodia could not stop the rise of the Khmer Rouge's power, which led to the overthrow of Lon Nol's government in 1975.

\section{B. 1979-1990 Dispute}

\section{Historical Background}

The Khmer Rouge defeated the Lon Nol régime and entered Phnoin Penh on April 17, 1975. One year later Pol Pot created a new constitution and renamed the country Democratic Kampuchea ("DK"). Sihanouk, whose alliance with Pol Pot significantly helped the Khmer Rouge gain international acceptance, was forced to step down in $1976 .{ }^{240}$ The Khmer Rouge later put Sihanouk under house arrest and murdered several members of his family. ${ }^{241}$ Initially greeted as "liberators" by the residents of Phnom Penh, the Khmer Rouge quickly became the ultimate oppressors. The three and one-half years following their takeover mark one of huniankind's greatest atrocities-an auto-genocide in which at least one million Cambodians were murdered, starved, or worked to death..$^{242}$ In 1988, the Under-Secretary-General and Senior Adviser to the United Nations described Cambodia in the period of 1975 to 1979 as a country of "ceaseless killings ... torture, persecution, iron discipline, ruthlessly inposed, hunger, starvation, deprivation of even the most elementary essentials of life. ${ }^{2243}$ Planning a communist utopia based on Maoist ideals, the Khiner Rouge forcibly evacuated all the major cities in Cambodia. ${ }^{244}$ Millions of city residents were sent into the countryside. Residents were ordered "to abandon their houses, their apartments, their shacks, their camps. They

240. See Mats Berdal \& Michael Leifer, Cambodia, in THE NEW INTERventionism 1991-1994, at 25, 28 (James Mayall ed., 1996).

241. See The War in Cambodia, supra note 215, at $666 \mathrm{n} .19$.

242. Estimates of the total death toll vary depending on the source. Vietnam estimated 3 million deaths, Amnesty International estimated 1.4 million, the U.S. Department of State estimated 1.2 million, and Khieu Samphan, a Khmer Rouge leader, estimated 1 million deaths. See Seekins, supra note 2 , at 51 .

243. KLINTworth, supra note 3, at 6 (quoting Sir Robert Jackson, Preface to Eva MYsLIWIEC, PUNishing the POOR, THE INTERNATIONAL IsOlation OF KAMPUCHEA, at iii (1988)).

244. See Seekins, supra note 2, at 48-55 (describing the mass evacuation of Phnom Penh and other cities and the Khmer Rouge's radical attempts to transform Cambodia into a communist society). Khmer Rouge leaders allegedly boasted in 1975 that their Democratic Kampuchea would be "the first nation to create a completely communist society without wasting time on intermediate steps." Id. at 52 . 
were told to take with them only the food they could carry. Those who were separated from their families were not allowed to seek them."245

Pol Pot recognized five classes of people in Cambodia before "year zero": 246 peasants, workers, bourgeoisie, capitalists, and feudalists. ${ }^{247}$ The Khmer Rouge systematically began ridding Cambodia of the latter three groups, either by "re-educating" thein through torture and forced labor, or, more often, through execution. ${ }^{248}$ Miscalculations as to the supplies necessary to sustain workers in the countryside, together with gross mismanagement of food production, led to mass starvation. Execution, starvation, disease-all contributed to the deaths at the hands of the Pol Pot régime. ${ }^{249}$ Reports of these human rights violations became known to the outside world within the first few years. ${ }^{250}$ Any Cambodian Communist Party member whose loyalty came under suspicion was not immune from Pol Pot's harsh retribution. Elements of the Party left the Khmer Rouge and escaped to Vietnam. Within Cambodia, repeated internal purges led to the torture and execution of many Khmer Rouge cadres. ${ }^{251}$

By 1978 , news of the situation was so grim that Britain raised the issue before the UN Commission on Human Rights. ${ }^{252}$ Over protests by Democratic Kampuchea and the Soviet Union that any consideration of the situation constitnted an intrusion into internal affairs, ${ }^{253}$ the Commission referred the matter to the Sub-Comnission on the Prevention of Discrimination and the Protection of Minorities to determine whether an investigation should be conducted..$^{254}$ The Sub-Commission received large amounts of evidence in favor of an investigation, but a Vietnamese invasion into Cambodia halted the imvestigative process. The negative international response to Vietnam's invasion was immediate and resounding. The Sub-Commission favored condemnation for "the systematic and gross

245. Shawcross, supra note 217 , at 367 ; see also Bennett \& Benson, supra note 244 , at 167 ; Seekins, supra note 2, at 53 (noting that "[f]amilies often were separated because people were divided into work brigades according to age and sex and sent to different parts of the country").

246. Po1 Pot's name for Cambodia's new beginning as a communist utopia was "year zero." See Seth Mydans, Endgame Begins for Khmer Rouge and Pol Pot, InT'L Herald TrIBune, Apr. 13, 1998, at 1.

247. See Seekins, supra note 2, at 51-52.

248. See id. at 50.

249. See Ratner, supra note 204, at 3 . While visiting Cambodia in the summer of 1997 , I found that every single Cambodian person with whom I spoke had lost one or more family members to the Khmer Rouge during this time period.

250. See Collin Warbrick, Kampuchea: Representation and Recognition, 30 INT'L \& COMP. L.Q. 234, 234 (1981).

251. See Solarz, supra note 205, at I02.

252. See U.N. ESCOR, 33d Sess., U.N. Doc. E/CN.4/L.1402 (1978).

253. See Commission on Human Rights, U.N. ESCOR, 33d Sess., Supp. No. 4, U.N. Doc. E/CN.4/1292 (I978); Note by the Secretary General, U.N. ESCOR, 33d Sess., U.N. Doc E/CN.4/1295 (1978).

254. See Commission on Human Rights Dec. 9(XXXIV), U.N. ESCOR, 33d Sess., Supp. No. 4, I 9, at 137, U.N. Doc. E/1978/34-E/CN.4/1292 (1978). 
violations of human rights which ... had taken place in Democratic Kampuchea"; 255 however, based on Vietnam's intervention in Cambodia, it recommended that no "concrete measures" be taken agamst Pol Pot at that time. ${ }^{256}$ The Sub-Commission submitted its recommendations to the thirtyfifth session of the Human Rights Commission, which then postponed its deliberations on the matter until the following session. ${ }^{257}$

Vietnam invaded Cambodia on December 24, 1978, and took the capital in early January. A variety of factors inspired the invasion: the alliance between China and Cambodia in China's dispute with Vietnam; the Khmer Rouge's abuse of ethnic Vietnamese in Cambodia; and increased border dispute flare-ups between the two countries. ${ }^{258}$ In addition to selfinterested motives, Vietnam's intervention may be seen, in part, as a humanitarian response to Pol Pot's commission of atrocities on a genocidal scale. ${ }^{259}$

A group of former Khmer Rouge cadres who fled to Vietnam in 1978 formed the United Front for the National Salvation of Kampuchea. Heng Samrin led this group and formed the core of the new Vietnamese-backed government in Canıbodia, the People's Republic of Kanipuchea ("PRK"). ${ }^{260}$ With the support of Vietnamese troops, the PRK quickly ganied control of most of the territory and all the primcipal population centers. ${ }^{261}$ However, the Khmer Rouge nuamtained control of territory along the Canubodian-Thai border and forced obedience of the populations within that territory. ${ }^{262}$ After the Vietnamese invasion, the United States was pressured to joni a coalition with the Khmer Rouge to combat the PRK government. ${ }^{263}$ The Coalition Government of Democratic Kanupuchea (CGDK) was officially established in 1982 with its headquarters located in refugee camps along the Thai border. ${ }^{264}$

\section{The Dispute}

The representation dispute arising from Vietnam's invasion of Canıbodia must be viewed withn its political context. Many inember states

255. U.N. ESCOR, 34th Sess., Supp. No. 6, II 223, at 55, U.N. Doc. E/1979/36-E/CN.4/1347 (1979).

256. Id.

257. See id. II 225.

258. See RoTH, supra note 6, at 449; Berdal \& Leifer, supra note 240, at 29 (attributing the invasion in part to "murderous attacks against civilian settlements across the border in southern Vietnam").

259. For a full argument supporting Vietnam's intervention as meeting the criteria for excusable humanitarian intervention, see KLINTWORTH, supra note 3, at 59-77. But cf. Solarz, supra note 205, at 102 n.3 (asserting that human rights played no role in Vietnam's decision to invade).

260. See RoTH, supra note 6, at 449-50.

261. See Warbrick, supra note 250 , at 235.

262. See Bennett \& Benson, supra note 244, at 168.

263. See The War in Cambodia, supra note 215, at 666 .

264. See RoTH, supra note 6, at 450-51; Bennett \& Benson, supra note 244, at 168. 
condemned Vietnam's invasion and the installation of the PRK as blatant foreign intervention in violation of the UN Charter. ${ }^{265}$ This outrage was equally a product of political interests, however, because

[a]lthough cloaked in principle, the Cambodian conflict was, in essence, about the balance of power in Indochina, with global as well as regional significance. At issue with the invasion of Cambodia was whether or not Vietnam was to become the dominant state in the peninsula. That inatter primarily involved a test of wills between Vietnam and China. ${ }^{266}$

Bolstered by the negative response toward Vietnam, Democratic Kampuchea requested that the UN Security Council address the issue of representation in January $1979 .^{267}$ The Security Council accepted this request and debated whether to formally reprimand Vietnam for its actions. The Security Council allowed a Khmer Rouge representative to speak, but refused the same opportunity for a PRK representative. This shutout of the PRK set the tone of the entire debate. ${ }^{268}$ If not for the use of the Soviet veto, the Security Council probably would have officially condemned the Vietnamese intervention against the Khmer Rouge. ${ }^{269}$

In September 1979, as the representation dispute remained unresolved, the General Assembly raised the representation issue as a separate agenda item and referred the examination of Deniocratic Kampuchea's credentials to the Credentials Committee for expeditious consideration. ${ }^{270}$ This urgency resulted from separate Khmer Rouge and PRK commumications each announcing an intent to send a delegation to the thirty-fourth session of the General Assembly. ${ }^{271}$ The nine members of the Credentials Committee were sharply divided on whether to accept the Khmer Rouge's

265. See U.N. GA. Provisional Verbatim Record, 34th Sess., 4th plen. mtg. at 32-36, 47, 49-50, 93-95, U.N. Doc. A/34/PV.4 (1979).

266. Berdal \& Leifer, supra note 240 , at 29 . For a more in-depth discussion of the politics of the region duriug this period, see generally GRANT EVANS \& KELVIN ROWLEY, RED BROTHERHOOD AT WAR (1984).

267. See U.N. SCOR, 34th Sess., Supp. for Jan.-Mar. 1979, at 3, U.N. Doc. S/13003 (1979). Under the current structure, representation disputes may be raised in any UN organ. See discussion supra Part II.A. The Security Council's opinion on a representation issue logically would carry some weight in subsidiary UN organs. Raising the dispute in the Security Council, however, does not eliminate the necessity of credentials verification by the Credentials Committee under Rule 27.

268. See Warbrick, supra note 250 , at 237-38.

269. A draft resolution condemuring Vietnam's intervention was proposed in the Security Council. See U.N. SCOR, 34th Sess., Supp. for Jan.-Mar. 1979, at 27, U.N. Doc. S/13027 (1979). The Security Council vote was thirteen members in favor of adopting the draft, two opposed; lowever, the USSR's negative vote served as a veto of the draft resolution. See U.N. SCOR, 34th Sess., 2112th plen. mtg. IIII 4, 24, U.N. Doc. S/PV.2112 (1979).

270. See U.N. GAOR, 34th Sess., 2 d plen. mtg., Agenda Item 6, I 16, at 18, U.N. Doc. A/34/PV.2 (1979).

271. See U.N. GAOR, 34th Sess., Annexes, Agenda Item 3, TII 5-6, at 1. U.N. Doc. A/34/500 (1979) [hereinafter First Report of the Credentials Comm.] 
credentials. They were also sharply divided on how broad the Committee's inquiry into the representation issue could be.

The Congo's representative initially proposed that neither delegation should be recognized until the Credentials Committee could coniprehensively evaluate the matter, an argument which originated from discussions of the Cambodian situation at various imternational conferences. ${ }^{272}$ The representatives of the USSR and Panama were open to the suggestion that the seat remain temporarily empty. ${ }^{273}$ The majority, however, supported acceptance of the Khmer Rouge credentials. China's representative argued that the challenge to the Khmer Rouge's credentials was unreasonable because Deniocratic Kampuchea was a sovereign state whose government's credentials were legal and valid. ${ }^{274}$ Further, he argued that the Cambodian people had repudiated the Vietnamese-backed "puppet régime."275 China's representative formally proposed acceptance of the Khmer Rouge credentials. ${ }^{276}$ The representatives of Pakistan, ${ }^{277}$ the United States, ${ }^{278}$ Senegal, ${ }^{279}$ Ecuador, ${ }^{280}$ and Belgium ${ }^{281}$ agreed.

The Committee's support for the Khmer Rouge endured despite several explanatory references concerning the human rights violations that Democratic Kampuchea committed. For example, the U.S. representative noted that "his country's abhorrence of the actions of the Government of Deniocratic Kampuchea towards its own people was a matter of record. However, the issue was not the conduct of a government toward its own nationals, but the validity of the credentials of the representatives of Democratic Kampuchea." ${ }^{282}$ Pakistan's representative, too, clarified that Pakistan was not "condoning the deplorable acts of the régime, ... [but] the task of the Credentials Committee was to decide whether the credentials of Democratic Kampuchea were valid or invalid."283

Another argument that favored Democratic Kampuchea as the régine to represent Cambodia in the UN was based on a narrow view of the Credentials Committee's charge. Senegal's representative expressed this position in remarking that it "was not up to the Committee to decide whether a government was good or bad.... If the credentials of the

272. The Congo's representative referred generally to "several international conferences," citing the most recent one as the Sixth Conference of Heads of State or Government of Non-Aligned Countries at Havana. Id. II 7, at 1.

273. See id. II 8 , at $1, \mathbb{I} 11$, at 2 .

274. See id. II 9 , at 2 .

275. Id.

276. See id.

277. See id. II 10, at 2 .

278. See id. II 12 , at 2 .

279. See id. II 13, at 2.

280. See id. II 14, at 2.

281. See id. $\mathbb{1} 17$, at 2 .

282. Id. II 12 , at 2 .

283. Id. I 10 , at 2 . 
Government were in order, the Credentials Committee should recommend to the General Assembly that the status quo be maintained."284 Ecuador's representative similarly noted that "the mandate of the Credentials Committee was confmed to ascertaining if credentials were in order. The proper forun for a debate on any other issue was the General Assembly."285 Belgium's representative agreed that the political aspect of the problem "could be discussed in the General Assenibly, while the Committee should confine itself to its technical task." 286

Following this discussion, the Credentials Committee submitted a draft resolution, passed by a vote of six in favor and three against, proposing that the General Assembly accept the credentials of the Khmer Rouge. ${ }^{287}$ This resolution included an amendnent proposing that the Cambodian seat remain temporarily vacant. ${ }^{288}$ Despite the arguments of Vietnam supporters that Cambodians led the civil war which ousted the Khmer Rouge régime, the majority of the General Assembly opposed Vietnam's intervention in Cambodia. ${ }^{289}$

The General Asseinbly first decided, through a vote, ${ }^{290}$ that the proposed amendment was not actually an amendment because it substantively changed the draft resolution. After this determination, the amendnient's supporters proposed that the General Assembly vote to accept the actual text of the amendment before voting on the Credentials Committee's report, but the Assembly rejected this proposal. ${ }^{291}$ Following the failure of the aniendnient, the General Assembly approved the draft resolution of the Credentials Committee ${ }^{292}$ by a vote of seventy-one in favor and thirty-five against, with thirty-four abstentions. This same dispute arose every year between 1980 and 1989, and every year the General Assembly accepted the credentials of the Khmer Rouge over those of the PRK. ${ }^{293}$

284. Id. I 13, at 2 .

285. Id. I 14 , at 2 .

286. Id. II 17 , at 2 .

287. See id. I23, at 2 .

288. See U.N. GAOR, 34th Sess., Annexes, Agenda Item 3, at 4, U.N. Doc. A/34/L.3 \& ADD.1 (1979). Normally, Credentials Committee members may propose any amendment to a Credentials Committee report. See General Assembly Rules of Procedure, supra note 57, Rules 120, 161. The General Assembly votes on amendments to a proposal before actually voting on the proposal itself. See id. Rule 90. Where an amendment substantially changes the proposal, as in the instance of this amendment's proposal for Cambodia's seat to remain temporarily vacant, the General Assembly may determine that the document is not actually an amendment. See infra note 290 and accompanying text.

289. See Bennett \& Benson, supra note 244, at 30 .

290. The vote was 80 in favor, 43 against, with 19 abstentions. See U.N. GAOR, 34th Sess., 4th plen. mtg., Agenda Item 3, II 290, at 56, U.N. Doc. A/34/PV.4 (1979).

291. The vote was 76 in favor of rejection, 39 against, with 23 abstentions. Id. I 292, at 56.

292. See id. II 293, at 56 .

293. The Credentials Committee report, which recommended acceptance of Democratic Kampuchea's credentials, was adopted without a vote each session. See U.N. GAOR, 44th Sess., 32d plen. mtg. at 36, U.N. Doc. A/44/PV.32 (1989); U.N. GAOR, 43d Sess., 33d plen. mtg., U.N. Doc. A/43/PV.33 (1988); U.N. GAOR, 42d Sess., 36th plen. mtg. at 26, U.N. Doc. A/42/PV.36 (1987); U.N. 
Throughout the 1980s, the United States provided aid and arms to the Khmer Rouge to support its efforts to overthrow the PRK. ${ }^{294}$ In an effort to stem the tide of criticism resulting from overt support of the Khmer Rouge, the United States pressured Sihanouk and another non-communist group to form a coalition governmeut with the Khmer Rouge, the Coalition Government of Democratic Kampuchea (CGDK). ${ }^{295}$ By turning attention away from the Khmer Rouge and toward Sihanouk, anti-Vietnam powers hoped to prevent the UN front eventually accrediting the PRK's delegation or from leaving Cambodia's seat enıpty. ${ }^{296}$ Despite this coalition, the Khmer Rouge maintamed control of the CGDK's foreign affairs; thus, the Khmer Rouge maintained control of Cambodia's representation in the UN General Assembly. ${ }^{297}$

\section{Analysis}

The procedural route of the 1979 dispute through the Credentials Committee and the General Assembly was similar to the route the dispute would have taken under the Accreditation Proposal. Under the Accreditation Proposal, the General Assembly would have immediately referred the dispute to the Credentials Committee before discussion on the issue, which is exactly what the General Assembly did in this case. Then, based on the Credentials Committee's report, the General Assembly would have then discussed the dispute and voted on the report, which it also did. Though the process of the dispute resolution mirrored that provided by the Accreditatiou Proposal, the substance of the Credentials Committee and General Assembly discussions and the ultimate outcome would have been very different under the Accreditation Proposal's balancing test.

Rather than undertake any substantive discussion of the complicated representation dispute, the majority in the Credentials Committee cloaked a very political decision in the procedural technicalities of Rule 27 of the Rules of Procedure of the General Assembly. ${ }^{298}$ In recommending that the General Assembly accept the Khmer Rouge as Cambodia's representative,

GAOR, 41st Sess., 45th plen. mtg. at 23-35, U.N. Doc. A/41/PV.45 (1986); U.N. GAOR, 40th Sess., 37th plen. mtg. at 37, U.N. Doc. A/40/PV.37 (1985); U.N. GAOR, 39th Sess., 32d plen. mtg. T1 111, at 652-53, U.N. Doc. A/39/PV.32 (1984); U.N. GAOR, 38th Sess., 34th plen. mtg. I 89, at 596, U.N. Doc. A/38/PV.34 (1983); U.N. GAOR, 37th Sess., 45th plen. mtg. III 13-14, at 772, U.N. Doc. A/37/PV.45 (1982); U.N. GAOR, 36th Sess., 3d plen. mtg. T 174, at 31 U.N. Doc. A/36/PV.3 (1981); U.N. GAOR, 35th Sess., 35th plen. mtg. 250 , at 718 U.N. Doc. A/35/PV.35 (1980).

294. See generally The War in Cambodia, supra note 215 (examining critically indirect U.S. aid to the Khmer Rouge throughout the 1980s). See, e.g., SHAwCROss, supra note 217.

295. See The War In Cambodia, supra note 215, at 666; see also Seekins, supra note 2, at 196 (describing the use of political pressure by China, the Association of South East Asian Nations, and the UN on the Khmer Rouge to form a coalition government and adopt a "new mode of behavior").

296. See Solarz, supra note 205, at 103.

297. See Bennett \& Benson, supra note 244, at 171.

298. See General Assembly Rules of Procedure, supra note 57, Rule 27. 
the Crcdentials Committee members justified their decision on a narrow, technical reading of Rule 27's text. The members repeatedly referred to Khmer Rouge human rights violations as political issues not appropriate for consideration in the credentials process. This reliance on the procedural nature of the credentials process served to shield the meinbers froin truly justifying their recognition of the Khmer Rouge in the face of that régime's egregious human rights violations. This reasoning completely disregarded the UN Legal Counsel's Opinion on the Scope of Rule 27, which broadened the reading of Rule 27 to include consideration of representation disputes. ${ }^{299}$ Under the Accreditation Proposal, both the Credentials Committee and the General Assembly wonld have been forced not only to discuss the Khmer Rouge's hunian rights violations, but to consider and weigli those violations in inaking their nltimate decisions.

The first factor in the Accreditation Proposal's balancing test, effective control, was not even considered in the 1979 dispute. Likely, the effective control issue was disregarded in this dispute because the PRK, albeit with the support of Vietnamese troops, ${ }^{300}$ controlled the vast majority of Cambodia's territory and population. Those ineinber states determined to keep the PRK out of Cambodia's UN seat would not admit that effective control existed because, as they argued, any control was gained and inaintained solely through foreign intervention and assistance, in violation of the UN Charter. ${ }^{301}$ The 1979 dispute remained focused on Vietnam's intervention, to the exclusion of all other considerations, including consideration of Democratic Kampuchea's acts. ${ }^{302}$

Under the Accreditation Proposal, the PRK's presumption of representation, based on its clear, effective control, would have been overcoine by its extensive reliance on Vietnam to achieve that control. As Vietnain's assistance to the PRK lessened over the years, ${ }^{303}$ and the PRK continued to inaintain effective control of Cainbodia on its own, this presumption could be regained in later representation disputes. However, for purposes of the initial 1979 dispute, the PRK would not be presumed to be representative. Despite the lack of presninption, the PRK's effective control would still weigh in its favor in the overall balance.

The Accreditation Proposal, in considering whether either régine naintained control through the willing consent of the population, would

299. See discussion supra Part II.B.3.

300. Note that the number of Vietnanese troops lessened throughout the years as the PRK gained strength within Cambodia. See KIINTWORTH, supra note 3, at 72.

301. See discussion supra Part IV.B.2.

302. This intensive focus on the Vietnanese backing of the PRK seems slightly out of proportion when compared to the discussion and outcome of the 1973 dispute, where the U.S. financial and military support to Lon Nol's government was disregarded almost entirely. See discussion supra Part IV.A.

303. See supra note 300 and accompanying text. 
not have favored either the PRK or Democratic Kampuchea, at least in the 1979 dispute. The Khmer Rouge gamed its control in 1975, and maintained that control through force and terror. ${ }^{304}$ The PRK was installed through Vietnam's invasion of Cambodia rather than through popular elections. Thus, m 1979 neither régime could claim the willing consent of the population. In later disputes between the PRK and Democratic Kampuchea, this factor might tip in favor of the PRK based on indications of willing consent, although any indications of consent would have to be measured against possible coercion through Vietnam's continued presence in Cambodia.

The consideration of the willingness and ability of either régime to fulfill Cambodia's UN Charter and.international obligations would be complicated by the global politics surrounding this dispute. Had the PRK come to power without Vietnam's assistance, this factor would be rather simple to evaluate. Democratic Kampuchea was not able to meet Cambodia's UN Charter and international obligations because the Khmer Rouge was forced into a guerrilla warfare existence near Cambodia's northern borders and maintained none of the control necessary to meet those obligations. ${ }^{305}$ During its reign, the Khmer Rouge also demonstrated that it was unwilling to meet certain UN Charter obligations, such as respect for human rights and self-determination embodied in Articles 1 and 55 of the Charter. ${ }^{306}$ The PRK maintamed the effective control necessary to meet Cambodia's obligations, and seemed willing to do so. This factor clearly would weigh in the PRK's favor had Vietnam not been involved.

However, Vietnam was significantly involved in Cambodian affairs. Its intervention into Cambodia's domestic affairs was viewed as a violation of Article 2, Paragraph 4, which prohibits such interference. ${ }^{307}$ This contravention of the Charter in establishing the PRK's control inevitably would taint any consideration of the PRK's willingness to meet Charter obligations. Thus, this factor likely would weigh against both régimies, although it might weigh more heavily against the Khmer Rouge since the PRK, practically speaking, had the ability to meet Cambodia's obligations.

Finally, under the Accreditation Proposal, the Credentials Committee and the General Assembly would have considered whether either régime respected the human rights of Cambodia's inhabitants, rather than skirting around the issue as both organs did in the actual dispute. Here, the scales of the balance would have tipped sharply agamst Deinocratic Kampuchea. As discussed in Parts IV.B.1 and 2, the Khmer Rouge committed massive, systematic human rights violations against Cambodia's iuhabitants,

304. See discussion supra Part IV.B.2.

305. See Warbrick, supra note 250, at 239.

306. See discussion supra Part III.B.3.

307. See U.N. CharTER art. 2, para. 4. 
resulting in the death of approximately one quarter of Cambodia's population. In comparison, the PRK largely respected the human rights of Cambodia's inhabitants. Vietnam's support of the PRK would not weigh against it in the consideration of human rights. This factor alone would tip the balance of the Accreditation Proposal firmly against a régime guilty of such widespread and egregious human rights violations as those the Khmer Rouge committed.

The Credentials Committee would have recommended the rejection of Democratic Kampuchea as Cambodia's representative under the Accreditation Proposal. Though the balance would have weighed in favor of accepting the PRK as Cambodia's representative, the political realities of the dispute might have mandated that the Committee reject the PRK as well. Thus, Cambodia's seat might have been left vacant temporarily; in later disputes, as Vietnam's presence in Cambodia lessened, this result would have become less acceptable as the PRK continued to control Cambodia in every other way. The General Assembly then would engage im a full application of the balancing test in deciding whether to accept or reject the Committee's recommendation. Though anti-Vietnam member states might view the rejection of Democratic Kampuchea's credentials as somehow condoning Vietnam's invasion, Democratic Kampuchea would not be accredited as Cambodia's representative if the General Assembly adhered to the Accreditation Proposal.

\section{1997 Dispute}

\section{Historical Background}

Cambodia experienced another credentials dispute in 1997. The decade prior to this dispute brought sigmificant political change to Cambodia. In 1987, Sihanouk broke ranks with the CGDK to enter negotiations with Hun Sen, the PRK's Prime Minister ${ }^{308}$ These talks, together with changing politics accompanying the dwindling Cold War, encouraged international participation in resolving the Cambodian conflict. ${ }^{309}$ Vietnam offered an unconditional withdrawal of all troops in 1989, and an international conference im Paris led to several agreements, including an "Agreement on a Comprehensive Political Settlement of the Cambodian Conflict" signed in October $1991 .{ }^{310}$

As a result of the agreements reached in Paris, the UN supervised Cambodian national elections in $1993 .{ }^{311}$ Among the parties running in this

308. See Bennett \& Benson, supra note 244, at 172; Berdal \& Leifer, supra note 240, at 32.

309. See Berdal \& Leifer, supra note 240 , at 32.

310. See id. at 33; Bennett \& Benson, supra note 244 , at 168,172 . For an extensive discussion of the Paris Agreement, see Ratner, supra note 204.

311. See Frederick Z. Brown, Cambodia, in A Global Agenda 53-54 (John Tessitore \& Susan Woolfson eds., 1998). 
election were the Royalist Party (FUNCINPEC), led by Sihanouk's son, Prince Norodom Ranariddh, and the Cambodian People's Party (CCP), led by Hun Sen, the former PRK Prime Minister. Ranariddh's FUNCINPEC party won nearly forty-five and one-half percent of the votes over the CCP's thirty-eight percent of the votes. ${ }^{312}$ Despite the election results, Hun Sen demanded a position as co-prime mimister in Cambodia's government and threatened civil war if excluded. ${ }^{313}$ To avoid a conflict in the face of Hun Sen's superior military power, Ranariddh reluctantly agreed to a coalition government with himself as First Prime Minister and Hun Sen as Second Prime Minister. ${ }^{314}$ This government led a tension-filled existence from 1993 until July 5, 1997, when Hun Sen seized power in a coup d'état. ${ }^{315}$

Ranariddh set up a government-in-exile, seeking international support for his efforts to bar recognition of Hun Sen's CCP. ${ }^{316}$ Hun Sen appointed Ung Huot, Ranariddh's forner Foreign Mimister, as the new First Prime Minister ${ }^{317}$ National elections were originally scheduled for May 1998, but the coup d'état effectively pushed the elections back until July 1998. Hun Sen defeated Ranariddh in the polls. ${ }^{318}$

\section{The Dispute}

The 1997 Cambodian representation dispute arose when both Ranariddh's Royalist party and Hun Sen's CCP submitted credentials for delegations to represent Cambodia in the General Assembly's fifty-second session. ${ }^{319}$ In a letter to the UN Secretary-General, Sihanouk, still the constitutional nionarch of Cambodia, designated Ung Huot and Hun Sen as Cambodia's representatives to the UN ${ }^{320}$ Ranariddh, with the support of the United States and Norway, opposed seating Hun Sen's government based on Sen's violent usurpation of power. ${ }^{321}$ The Credentials Committee considered the credentials of each delegation on September 17 and 19,

312. See William Shawcross, The Nightmare Is Over, N.Y. Tmmes, Oct. 12, 1993, at A23; Philip Shenon, Eastern Cambodia Moves to Secede, N.Y. Thmes, June 13, 1993, at L9.

313. See Shawcross, supra note 312; Shenon, supra note 312.

314. See Brown, supra note 311 , at 54 .

315. See Keith B. Richburg, Coup Ousts Cambodian Prince, WASH. Post, July 8, 1997, at A1.

316. See Robin McDowell, Cambodian Leaders Fly to New York After Being Barred from United Nations, A.P., Sept. 21, 1997, available in 1997 WL 4884489.

317. See Farhan Haq, Stalemate over Cambodian Recognition at U.N., INTER Press Service, Sept. 17, 1997, available in 1997 WL 13256632.

318. See The Economist Intelligence Unit, Country Report: Cambodia, Laos (1998), available in 1998 WL 22842247 [hereinafter COUNTRY REPORT]

319. See U.N. GAOR, 52d Sess., Agenda Item 3, I 4, U.N. Doc. A/52/719 (1997) [hereinafter Report of the Credentials Comm.].

320. See id.

321. See Haq, supra note 317; Deborah Seward, Cambodian Leader Hun Sen Threatened Wednesday, A.P. PoL. SERVICE, Sept. 24, 1997, available in 1997 WL 2551525. 
$1997 .{ }^{322}$ Despite the U.S. representative's strong lobbying efforts to preserve the seat for Ranariddh, ${ }^{323}$ the Credentials Committee "having considered the question of the credentials of Cambodia, decided to defer a decision on the credentials of Cambodia on the understanding that, pursuant to the applicable procedures of the Assembly, no one would occupy the seat of that country at the fifty-second session."324

Following this decision, Hun Sen threatened to bar the UN from momitoring or observing the 1998 elections if his government was not recogmized as the legitimate authority of Cambodia. ${ }^{325}$ Despite these threats, the General Assembly accepted the Credentials Committee's recommendations and Cambodia's UN seat remained vacant for the fifty-second session. ${ }^{326}$ The Cambodian national elections took place July 26, 1998. Hun Sen narrowly defeated Ranariddh at the polls. ${ }^{327}$ Ranariddh initially disputed the election results and blocked the formation of a new government. ${ }^{328}$ Under international pressure, Ranariddh agreed to join a coalition government with Hun Sen in November; the coalition named Hun Sen as Prime Minister and appointed Ranariddh as President of the National Assembly. ${ }^{329}$ The formation of a coalition government cleared the way for the Credentials Committee to accept its credentials. In early December, the General Assembly approved, by consensus without a vote, the Credentials Committee's recommendation to give Cambodia's seat to the coalition government led by Hun Sen. ${ }^{330}$ Cambodia's Minister of State for Foreign Affairs, Hor Namhong, arrived to represent Cambodia for the remainder of the General Assembly's fifty-third session. ${ }^{331}$

\section{Analysis}

More than either of the earlier Caunbodian representation disputes, the General Assembly's actual resolution of the 1997 dispute is im accord with the inanner in which the Accreditation Proposal would have decided the conflict. The first factor of the Accreditation Proposal, effective control, favors Hun Sen over Ranariddh. Hun Sen dommated the inilitary forces and quickly took physical control of the majority of Cambodia's territory. The notable exception was territory still controlled by the Khmer Rouge. Following Hun Sen's aggressive attacks and the death of Pol Pot in April

322. See Report of the Credentials Comm., supra note 319, 14.

323. See Barbara Crossette, Cambodian Might Bar the U.N. from Vote if Denied Vacant Seat, N.Y. TIMEs, Oct. 1, 1997, at A10.

324. See Report of the Credentials Comm., supra note 319 , II 5.

325. See Crossette, supra note 323; Seward, supra note 321.

326. See U.N. GAOR, 52d Sess., 76th plen. mtg., U.N. Doc. A/Res/52/178 (1997).

327. See COUNTRY REPORT, supra note 318.

328. See Cambodia's U.N. Seat Approved, A.P., Dec. 7, 1998, available in 1998 WL 23509060.

329. See id.

330. To be reported in U.N. GAOR, 53d Sess., 80th plen. mtg., U.N. Doc. A/53/PV.80 (1998).

331. See Cambodia's UN Seat Approved, supra note 328. 
1998, the Khmer Rouge was greatly crippled and lost much of its former territory to Hun Sen. ${ }^{332}$ I am aware of no major external assistance from foreign powers on either side of the conflict. Thus, under the effective control test Hun Sen would achieve a presumption of representation.

The next factor, willing consent of the people, would work against this presumption based on the method through which Hun Sen gained power. After losing in the 1993 national elections, Hun Sen forced his way into a coalition government with Ranariddh. When Hun Sen took sole control of Cambodia in July 1997, he did so through a military coup d'état. Neither of these methods of gaining power reflect a willing consent of the population to be governed by Hun Sen. Further, he threatened Ranariddh with criminal proceedings if Ranariddh attempted to return to Cambodia, effectively eliminating his competition, at least temporarily. ${ }^{333}$ The degree to which this factor could work against the presumption of representation would depend on the specifics of the particular situation. Here, Hun Sen's bullying tactics would probably work strongly against him in the overall balance. This factor would weigh in favor of Ranariddh, at that time the only elected leader of Cambodia.

Hun Sen's threats in 1997 that he would bar UN participation in Cambodia if his government was not given Cambodia's seat weigh against him under the willingness to meet UN Charter obligations factor of the Accreditation Proposal. Hun Sen threatened to put UN representatives in Cambodia "on vacation"334 until the seat was filled. He also sought to remove officials from the UN Centre for Human Rights in Phnom Penh, Cambodia. ${ }^{335}$ Hun Sen's unwillingness to work with the UN unless given his way weighs against him. Because the UN Charter does not create direct obligations, however, the weight would be minor. In contrast, Ranariddh supported the UN decision to leave Cambodia's seat vacant, and pressed the UN to help ensure fair and free elections within Cambodia. Ranariddh's apparent willingness to meet UN obligations would weigh in his favor.

The Centre for Human Rights collected evidence that Hun Sen was guilty of human rights abuses following the 1997 coup, ${ }^{336}$ especially abuses directed against Ranariddh's military officers and civilian leaders. ${ }^{337}$ The Centre for Human Rights estimated that more than 100 people in Cambodia were killed following the coup. ${ }^{338}$ These abuses weigh against

332. See End of Movement, State Journal-Register (Springfield, IL), May 3, 1998, at 2, available in LEXIS, News Library, STJREG File.

333. See Crossette, supra note 323.

334. Seward, supra note 321.

335. See id.

336. See Haq, supra note 317.

337. See Brown, supra note 311, at 54 .

338. See id. 
Hun Sen yet again. Thus, though Hun Sen retained effective control in Cambodia, all the other factors indicate that he did not truly represent the people. Considering that a national election was scheduled for 1998 in Cambodia, it was logical to leave Cambodia's seat vacant until the elections were held. ${ }^{339}$ The implied intent of this decision was to fill the seat following a sufficiently free and fair election.

Once Hun Sen won the national election and Ranariddh joined his coalition government, it was appropriate for the Credentials Committee and General Assembly to fill Cambodia's seat with this new coalition government. Whether this coalition government will fare better than the last coalition government, only time will tell. For the sake of Cambodians who have endured far more than their share of instability and civil war, one can only hope that, above all else, peace will reign until and beyond the next scheduled elections in May 2003. . $^{340}$

\section{CONCLUSION}

The international community is in a state of flux as the twentieth century draws to a close. The focus of international law continues to shift away from absolute state sovereignty toward a more interdependent systein which values human rights and fundamental freedouns. The UN has played an important role in the progress already made, and stands in a umique position to lead the way for international institutions in incorporating these values into their decision-making processes. The Accreditation Proposal presented in this Comment provides a valuable and praginatic starting point for the process of institutional change.

The Credentials Committee is already involved in the resolution of representation disputes; thus, the Accreditation Proposal would not require any radical structural changes to the existing UN procedure. The Accreditation Proposal, however, would provide needed, concrete guidelines for both the Credentials Committee and General Assembly to rely on in determining representation. These guidelines would proinote the recognition and protection of human rights within nember states, while fostering more consistent outcomes in representation disputes. Perhaps guidelines of this sort were too far ahead of their time when they were first proposed in 1950, prior to the passage of Resolution 396(V), but this is certainly no longer the case. The representation disputes involving Cambodia in 1973, 1979, and 1997 illustrate the continued need for

339. It is interesting to note that at the same time Cambodia presented two sets of credentials to the Credentials Committee, Afghanistan did the same. While the Committee recommended that Cambodia's seat remam empty, it deferred a decision about the Afghamistan dispute, but allowed the prior representative to retain Afghanistan's seat until the issue was decided. See Report of the Credentials Comm, supra note 319, 111 9-10.

340. See COUNTRY REPORT, supra note 318. 
consistent evaluation methods, including normative considerations of effective control, willing consent of the population, willingness to meet UN and other international obligations, and respect for human rights and fundamental freedoms.

The integration of human rights and fundamental freedoms into the fabric of the international community is a slow, and often arduous, task. The adoption of the Accreditation Proposal would be a relatively small step for a giant institution such as the UN, but it would constitute significant progress for the liuman rights movement. Even if the UN continues to cling to the façade that its accreditation process is merely procedural, human rights law will continue to move forward and gain importance. But as the international community prepares to enter the twenty-first century, the Gcneral Assembly should keep in imind a familiar proverb: A thousand mile journey begins with a single step. 